\title{
Loopbanen na de Universiteit Maastricht: meting 2000 : afstudeercohort 1988/1989 en 1993/1994
}

Citation for published version (APA):

Jacob-Tacken, K. H. M., \& Ramaekers, G. W. M. (2001). Loopbanen na de Universiteit Maastricht: meting 2000 : afstudeercohort 1988/1989 en 1993/1994. Researchcentrum voor Onderwijs en Arbeidsmarkt, Faculteit der Economische Wetenschappen. ROA Reports No. 5

https://doi.org/10.26481/umarep.2001005

Document status and date:

Published: 01/01/2001

DOI:

10.26481/umarep.2001005

Document Version:

Publisher's PDF, also known as Version of record

\section{Please check the document version of this publication:}

- A submitted manuscript is the version of the article upon submission and before peer-review. There can be important differences between the submitted version and the official published version of record.

People interested in the research are advised to contact the author for the final version of the publication, or visit the DOI to the publisher's website.

- The final author version and the galley proof are versions of the publication after peer review.

- The final published version features the final layout of the paper including the volume, issue and page numbers.

Link to publication

\footnotetext{
General rights rights.

- You may freely distribute the URL identifying the publication in the public portal. please follow below link for the End User Agreement:

www.umlib.nl/taverne-license

Take down policy

If you believe that this document breaches copyright please contact us at:

repository@maastrichtuniversity.nl

providing details and we will investigate your claim.
}

Copyright and moral rights for the publications made accessible in the public portal are retained by the authors and/or other copyright owners and it is a condition of accessing publications that users recognise and abide by the legal requirements associated with these

- Users may download and print one copy of any publication from the public portal for the purpose of private study or research.

- You may not further distribute the material or use it for any profit-making activity or commercial gain

If the publication is distributed under the terms of Article $25 \mathrm{fa}$ of the Dutch Copyright Act, indicated by the "Taverne" license above, 


\section{Loopbanen na de Universiteit Maastricht:}

Meting 2000

Afstudeercohort 1988/1989 en 1993/1994

ROA-R-2001/5

K.H.M. Jacob-Tacken

G.W.M. Ramaekers

\section{Researchcentrum voor Onderwijs en Arbeidsmarkt}

Faculteit der Economische Wetenschappen en Bedrijfskunde Universiteit Maastricht

Maastricht, augustus 2001 
ISBN 90-5321-317-1

Sec01.220 


\section{Inhoud}

Bladzijde

Voorwoord i

Samenvatting

1 Inleiding 1

1.1 Arbeidsmarktscanner Universiteit Maastricht 1

$\begin{array}{ll}1.2 \text { Onderzoekspopulatie } & 1\end{array}$

1.3 Vraagstelling en opbouw van het rapport 3

2 Ontwikkeling van de arbeidsmarktpositie tijdens de loopbaan 5

2.1 Maatschappelijke positie 5

2.1.1 Maatschappelijke positie vijf en tien jaar na afstuderen 5

2.1.2 Ontwikkeling van de maatschappelijke positie in vergelijking met het begin van de loopbaan $\quad 6$

$\begin{array}{ll}2.2 \text { Baankenmerken } & 7\end{array}$

$\begin{array}{lll}\text { 2.2.1 Baankenmerken vijf en tien jaar na afstuderen } & 7\end{array}$

2.2.2 Ontwikkeling van baankenmerken in vergelijking met het
begin van de loopbaan
ber

$\begin{array}{ll}2.3 \text { Vervolgopleiding } & 15\end{array}$

$\begin{array}{ll}2.4 & \text { Buitenlandervaring } \\ 2.5 & \text { Conclusie }\end{array}$

$\begin{array}{ll}2.5 \text { Conclusie } & 17\end{array}$

3 Werkrelevante competenties 19

3.1 Gebruik van competenties vijf en tien jaar na afstuderen $\quad 19$

3.2 Vereist niveau van competenties vijf en tien jaar na afstuderen 20

3.3 Relevantie van competenties in vergelijking met het begin van de loopbaan

3.4 Benutting en ontwikkeling van competenties vijf en tien jaar na afstuderen

$\begin{array}{lll}3.5 & \text { Conclusie } 26\end{array}$

4 Typering van banen $\quad 27$

4.1 Type banen $\quad 27$

4.2 Gebruik van competenties in elk type baan 29

4.3 Vereist niveau van competenties in elk type baan 30

4.4 Benutting en ontwikkeling van competenties in elk type baan 31

4.5 Conclusie 32 
5 Rol van de opleiding bij de ontwikkeling van competenties

5.1 Leerbronnen van competenties

5.2 Ervaren tekorten in de opleiding

5.3 Voorbereiding van de opleiding op het werk

5.4 Conclusie

Bijlage 


\section{Voorwoord}

Het Researchcentrum voor Onderwijs en Arbeidsmarkt (ROA) verricht sinds 1990 periodiek onderzoek naar de arbeidsmarktintrede en vanaf 1998 ook periodiek onderzoek naar de loopbanen van afgestudeerden van de Universiteit Maastricht. Dit gebeurt in opdracht van het College van Bestuur. De Arbeidsmarktscanner van de Universiteit Maastricht (UM Scanner) is een langlopend project waarbij alumni circa anderhalf, vijf en tien jaar na afstuderen een schriftelijke vragenlijst ontvangen. Voor afgestudeerden die na anderhalf jaar een vragenlijst ontvangen, staat de arbeidsmarktintrede centraal. Met deze meting wordt inzicht verkregen in de overgang van studie naar werk. Bij de vragenlijsten die alumni vijf jaar en tien jaar na hun afstuderen ontvangen, staat het loopbaanverloop centraal.

De data van de UM Scanner maken een analyse van het loopbaanverloop op zowel de korte als de lange termijn mogelijk. In dit rapport worden de resultaten gepresenteerd van de in het voorjaar van 2000 gehouden metingen onder afgestudeerden van de Universiteit Maastricht uit 1988/'89 (afstudeercohort '89) circa tien jaar na afstuderen en afgestudeerden uit 1993/'94 (afstudeercohort '94) circa vijf jaar na afstuderen. De vragenlijsten van deze metingen zijn ontwikkeld in een breder kader, te weten het internationale CHEERS-project (Careers after Higher Education: a European Research Survey) waarin elf Europese landen en Japan participeren. In dit project wordt onderzoek gedaan naar de loopbaanontwikkeling van afgestudeerden in het hoger onderwijs. Het ROA neemt hieraan deel als vertegenwoordiger van Nederland.

De in het voorjaar van 2000 gehouden metingen zijn in samenwerking met het Bureau Inschrijvingen van de Dienst Studentenzaken van de Universiteit Maastricht uitgevoerd. Het Bureau Inschrijvingen zorgt voor het bijhouden van het adressenbestand van de alumni, het verzenden van de vragenlijsten, en de non-responsactiviteiten. Het ROA is verantwoordelijk voor de methodologische en inhoudelijke aspecten van het project, de jaarlijkse rapportages, en het beheer van de onderzoeksgegevens. Aan deze rapportage hebben drs. Ger Ramaekers (projectleider) en drs. Karin Jacob-Tacken meegewerkt. De auteurs bedanken dr. Jim Allen voor zijn commentaar op een eerdere versie van dit rapport.

Maastricht, augustus 2001 


\title{
Samenvatting
}

\author{
Loopbaanontwikkeling \\ Wanneer we kijken naar de loopbanen van UM-afgestudeerden, dan zien we dat \\ men gaandeweg de loopbaan vaker een vaste aanstelling krijgt, minder vaak fulltime \\ gaat werken, vaker alsnog een functie op wo niveau krijgt en meer gaat verdienen. \\ Gaandeweg de loopbaan lijkt de combinatie van werk en gezin belangrijker te \\ worden.
}

\section{Voor het werk vereiste competenties}

Zeer goed zelfstandig kunnen werken en beschikken over zeer goede communicatieve vaardigheden is vaak belangrijk in de banen van UM-afgestudeerden. Daarnaast is het belangrijk dat UM-afgestudeerden goed initiatief kunnen nemen, kunnen plannen en organiseren, kunnen omgaan met- en inspelen op veranderingen, nauwkeurig zijn, kunnen werken in teamverband en over voldoende vakkennis beschikken. Internationale oriëntatie, met cijfers om kunnen gaan en leidinggeven is minder vaak belangrijk. Wat de relevantie van competenties betreft verandert er gaandeweg de loopbaan niet veel. Alleen plannen en organiseren blijkt gaandeweg de loopbaan belangrijker te worden. De meerderheid van de UMafgestudeerden heeft een baan waarin hij/zij zijn/haar competenties goed kan benutten en ontwikkelen.

De banen van economen worden gekenmerkt door het omgaan met cijfers, computergebruik en internationale oriëntatie. Voor de banen van medici en juristen is een zeer goede beheersing van vakspecifieke kennis en vaardigheden en nauwkeurigheid belangrijk. Juristen blijken relatief vaak 'solo-functies' te hebben. Voor de banen van gezondheidswetenschappers is een zeer goede beheersing van vakspecifieke kennis en vaardigheden minder belangrijk, maar zijn generieke vaardigheden zoals werken in teamverband en plannen en organiseren belangrijker.

\section{Type banen}

Er zijn drie type banen te onderscheiden. Het eerste type betreft banen met veel statusgerichtheid die gekenmerkt worden door macht en invloed, hoog salaris, sociale status en carrièreperspectieven. Vooral economen hebben dit soort banen. In deze banen wordt vaak een zeer goede beheersing van organisatorische competenties vereist. Daarnaast dient men in dit type banen zeer goed om te kunnen gaan met mensen en is zeer goed om kunnen gaan met cijfers belangrijk.

Het tweede type betreft banen met veel intellectuele ontwikkeling die gekenmerkt worden door het goed kunnen toepassen van kennis en vaardigheden, mogelijkheden om bij te leren en inbreng van eigen ideeën. Vooral medici en juristen hebben dit soort banen. In deze banen is vaak een zeer goede beheersing van vakspecifieke 
kennis en vaardigheden en nauwkeurigheid vereist en heeft men veel mogelijkheden om kennis en vaardigheden te benutten en te ontwikkelen.

Het derde type betreft banen met veel sociale gerichtheid die gekenmerkt worden door het hebben van genoeg tijd voor de vrijetijdsbesteding, maatschappelijk nut, goede sfeer en duidelijk gestructureerde werktaken. In deze banen is een zeer goede beheersing van specifieke competenties minder belangrijk en heeft men minder ruimte voor de benutting en ontwikkeling van kennis en vaardigheden.

Rol van de opleiding bij de ontwikkeling van competenties

Voor de meeste competenties is het werk een belangrijkere leerbron dan de opleiding. Computergebruik, plannen en organiseren, leidinggeven, omgaan met- en inspelen op veranderingen blijkt men voornamelijk op het werk te leren. Voor vakspecifieke kennis en vaardigheden en werken in teamverband blijkt naast het werk ook de opleiding een belangrijke leerbron te zijn. Andere competenties, zoals communicatieve vaardigheden, zelfstandigheid, nauwkeurigheid, creativiteit worden ook vaak elders geleerd.

In de opleiding worden vooral tekorten ervaren met betrekking tot computergebruik, plannen en organiseren, leidinggeven en omgaan met en inspelen op veranderingen. De in de opleiding opgedane kennis en vaardigheden alleen zijn vaak onvoldoende om het werk adequaat te kunnen vervullen, maar geven wel een goede basis voor de verdere ontwikkeling van kennis en vaardigheden. De meerderheid van de UMafgestudeerden heeft achteraf bezien geen spijt van de gemaakte opleidingskeuze. 


\section{Inleiding}

\subsection{Arbeidsmarktscanner Universiteit Maastricht}

Het project Arbeidsmarktscanner UM behelst een langlopend onderzoek naar de arbeidsmarktintrede en loopbaanontwikkeling van oud-studenten van de Universiteit Maastricht (UM). Het onderzoek gebeurt in opdracht van het College van Bestuur van de UM en wordt verricht door het Researchcentrum voor Onderwijs en Arbeidsmarkt (ROA) in samenwerking met de Dienst Studentenzaken. Het onderzoek bestaat jaarlijks uit drie schriftelijke metingen: namelijk circa een jaar na afstuderen, en vanaf 1998 circa vijf en tien jaar na afstuderen. Bij de meting een jaar na afstuderen staat de arbeidsmarktintrede centraal, terwijl bij de metingen vijf en tien jaar na afstuderen kenmerken van de verdere loopbaan centraal staan. Over de meting een jaar na afstuderen wordt apart verslag gedaan. In dit rapport zullen de metingen vijf en tien jaar na afstuderen beschreven worden. Deze zijn in het voorjaar van 2000 afgenomen.

De meting vijf jaar na afstuderen heeft betrekking op afgestudeerden van de Universiteit Maastricht uit het studiejaar 1993/94 (afstudeercohort '94). De meting tien jaar na afstuderen heeft betrekking op afgestudeerden van de Universiteit Maastricht uit het studiejaar 1988/89 (afstudeercohort '89). De vragenlijsten die beide cohorten hebben ontvangen zijn grotendeels gelijk. Deze vragenlijsten zijn ontwikkeld in een breder kader, namelijk het internationale CHEERS-project (Careers after Higher Éducation: a European Research Survey) waarin onderzoek gedaan wordt naar de loopbaanontwikkeling van afgestudeerden in het hoger onderwijs in elf Europese landen en Japan, waarbij het ROA vanuit Nederland is betrokken. De gehanteerde vragenlijst bevat informatie over persoonskenmerken zoals geslacht, over maatschappelijke positie, over baankenmerken, zoals loon, voltijd/deeltijd werk, vaste aanstelling en aansluiting tussen opleiding en functie, over het gebruik en niveau van competenties en over het oordeel ten aanzien van de gevolgde opleiding.

\subsection{Onderzoekspopulatie}

Op de vragenlijst van de Arbeidsmarktscanner heeft iets minder dan de helft van de in 1993/94 en 1988/1989 afgestudeerden van de UM gerespondeerd (zie tabel 1.1). Dit is een vrij hoog responspercentage aangezien de vragenlijsten respectievelijk vijf en tien jaar na afstuderen verstuurd zijn. Zo'n lange tijd na afstuderen is een aantal adressen niet meer actueel, waardoor een deel van de respondenten niet bereikt kon worden.

In tabel 1.1 is te zien dat het responspercentage bij afstudeercohort ' 89 iets hoger (48\%) lag dan bij afstudeercohort '94 (40\%). Verder bleek dat de respons onder medici (FdG) en gezondheidswetenschappers (FdGW) hoger was dan de respons onder economen (FdEWB) en juristen (FdR). Van de achttien economen uit cohort '89 bleken er slechts vier te hebben gerespondeerd. Aangezien deze groep zo klein 
is, zal hierover niet apart gerapporteerd worden. Gezondheidswetenschappers zijn de grootste groep in onze steekproef.

Tabel 1.1

Respons

\begin{tabular}{lccccccccccr}
\hline & \multicolumn{2}{c}{ FdEWB } & \multicolumn{2}{c}{ FdG } & \multicolumn{2}{c}{ FdGW } & \multicolumn{2}{c}{ FdR } & \multicolumn{2}{c}{ UM Totaal } \\
& '89 & '94 & '89 & '94 & '89 & '94 & '89 & '94 & '89 & '94 \\
& & & & & & & & & & & \\
\hline $\begin{array}{l}\text { Totaal aantal } \\
\text { afgestudeerden }\end{array}$ & 18 & 260 & 100 & 127 & 139 & 400 & 121 & 212 & 378 & 999 \\
$\begin{array}{l}\text { Aantal } \\
\text { respondenten }\end{array}$ & 4 & 91 & 61 & 56 & 81 & 192 & 35 & 64 & 181 & 403 \\
Respons in \% & 22 & 35 & 61 & 44 & 58 & 48 & 29 & 30 & 48 & 40 \\
\hline
\end{tabular}

Voor 308 van de 403 afgestudeerden uit cohort '94 kan een koppeling gemaakt worden met de gegevens uit de meting een jaar na afstuderen (zie tabel 1.2). Dit betekent dat er een vergelijking gemaakt kan worden tussen kenmerken van het werk tijdens de intrede op de arbeidsmarkt en het werk tijdens de verdere loopbaan. De groep medici en juristen is echter niet groot genoeg om betrouwbare conclusies te kunnen trekken. Voor cohort ' 89 is deze koppeling niet mogelijk, omdat de vragenlijst van tien jaar geleden op een aantal relevante punten nogal verschilt van de huidige vragenlijst. Bovendien is het aantal respondenten uit cohort ' 89 vrij klein. Dit komt doordat het aantal afgestudeerden aan de destijds nog prille UM een stuk kleiner was dan thans het geval is.

Tabel 1.2

Onderzoekspopulatie gekoppeld bestand een en vijf jaar na afstuderen, cohort '94

\begin{tabular}{lccccc}
\hline & FdEWB & FdG & FdGW & FdR & UM Totaal \\
\hline $\begin{array}{l}\text { Aantal } \\
\text { respondenten }\end{array}$ & 75 & 38 & 155 & 40 & 308 \\
\hline
\end{tabular}

Over het algemeen studeren er meer vrouwen dan mannen aan de Universiteit Maastricht (zie tabel 1.3). Alleen bij economie is het omgekeerde het geval: deze studie wordt door meer mannen dan vrouwen gevolgd. Het merendeel van de UMafgestudeerden heeft een vwo-diploma als hoogst voltooide vooropleiding. Van de in 1993/94 afgestudeerde juristen en gezondheidswetenschappers blijkt een klein deel een andere vooropleiding te hebben. Dit komt waarschijnlijk doordat aan deze twee faculteiten de opleiding ook in deeltijd kan worden gevolgd. 
Tabel 1.3

Achtergrondkenmerken cohort '89 en cohort '94

\begin{tabular}{|c|c|c|c|c|c|c|c|c|c|c|}
\hline \multirow[b]{2}{*}{ Cohort: } & \multicolumn{2}{|c|}{ FdEWB } & \multicolumn{2}{|c|}{ FdG } & \multicolumn{2}{|c|}{ FdGW } & \multicolumn{2}{|c|}{$\mathrm{FdR}$} & \multicolumn{2}{|c|}{ UM Totaal } \\
\hline & $\begin{array}{r}\text { '89 } \\
\%\end{array}$ & $\begin{array}{r}\text { '94 } \\
\%\end{array}$ & $\begin{array}{r}\text { '89 } \\
\%\end{array}$ & $\begin{array}{l}' 94 \\
\%\end{array}$ & $\begin{array}{r}' 89 \\
\%\end{array}$ & $\begin{array}{r}\text { '94 } \\
\%\end{array}$ & $\begin{array}{r}\text { '89 } \\
\%\end{array}$ & $\begin{array}{r}\text { '94 } \\
\%\end{array}$ & $\begin{array}{r}\text { '89 } \\
\%\end{array}$ & $\begin{array}{r}' 94 \\
\%\end{array}$ \\
\hline \multicolumn{11}{|l|}{ Geslacht } \\
\hline Man & - & 69 & 42 & 39 & 25 & 22 & 35 & 41 & 33 & 38 \\
\hline Vrouw & - & 31 & 58 & 61 & 75 & 78 & 65 & 59 & 67 & 62 \\
\hline \multicolumn{11}{|l|}{ Vooropleiding } \\
\hline Vwo/hbs/gym & - & 96 & 95 & 100 & 98 & 93 & 97 & 91 & 97 & 94 \\
\hline $\mathrm{Hbo}$ & - & 1 & 0 & & 1 & 4 & 3 & 2 & 1 & 2 \\
\hline Overig & - & 3 & 5 & & 1 & 4 & 0 & 8 & 2 & 4 \\
\hline \multicolumn{11}{|l|}{ Opleidingsvorm } \\
\hline Voltijd & - & 100 & 100 & 100 & 100 & 78 & 100 & 88 & 100 & 87 \\
\hline Deeltijd & - & & & & & 22 & & 13 & & 13 \\
\hline $\begin{array}{l}\text { Aantal } \\
(\mathrm{n}=100 \%)\end{array}$ & 4 & 90 & 59 & 56 & 81 & 190 & 34 & 63 & 178 & 399 \\
\hline
\end{tabular}

'-' de groep is te klein om over te rapporteren

\subsection{Vraagstelling en opbouw van het rapport}

Het doel van dit rapport is meer zicht te krijgen op de loopbanen van UM-afgestudeerden. De centrale vraag in dit rapport is dan ook:

Hoe ontwikkelen de loopbanen van afgestudeerden van de Universiteit Maastricht zich?

Deze vraag zal verder uitgesplitst worden in vier deelvragen die elk in een hoofdstuk zullen worden behandeld.

1. Hoe ontwikkelt de arbeidsmarktpositie van afgestudeerden van de Universiteit Maastricht zich tijdens de loopbaan?

In hoofdstuk twee zal gekeken worden naar de arbeidsmarktpositie van in 1993/94 en in 1988/89 UM-afgestudeerden respectievelijk vijf en tien jaar na afstuderen. Hierbij zal gekeken worden naar de maatschappelijke positie, naar een aantal baankenmerken (vaste aanstelling, fulltime/parttime, opleidingsrichting en -niveau van de baan en hoeveel zij verdienen), naar het volgen van een vervolgopleiding en het opdoen van buitenlandervaring. Daarnaast zal voor afstudeercohort '94 ook bekeken worden in hoeverre hun arbeidsmarktpositie vijf jaar na afstuderen is veranderd in vergelijking met het begin van hun loopbaan. 
2. Welke competenties zijn belangrijk in het werk van afgestudeerden van de Universiteit Maastricht?

In hoofdstuk drie zal gekeken worden naar de kennis, vaardigheden en houdingsaspecten oftewel de competenties die belangrijk zijn in het werk van UMafgestudeerden. Hierbij zullen we bekijken hoe vaak bepaalde competenties gebruikt worden en op welk niveau deze competenties beheerst moeten worden. Of de relevantie van competenties verandert tijdens de loopbaan zal eveneens aan de orde komen. Tenslotte wordt in dit hoofdstuk bekeken in hoeverre UM-afgestudeerden hun competenties in het werk kunnen benutten en ontwikkelen.

3. Hoe kunnen de banen van afgestudeerden van de Universiteit Maastricht getypeerd worden?

In hoofdstuk vier zal nader ingegaan worden op het type banen dat afgestudeerden van de Universiteit Maastricht hebben. Er zal een indeling gemaakt worden in drie type banen en per type baan zal bekeken worden welke competenties belangrijk zijn.

4. Welke rol speelt de opleiding bij de ontwikkeling van competenties?

In hoofdstuk vijf zullen we kijken naar de rol die de opleiding speelt bij de ontwikkeling van competenties. Allereerst zal nagegaan worden waar UMafgestudeerden hun competenties geleerd hebben. Vervolgens zal bekeken worden of UM-afgestudeerden tijdens de opleiding bepaalde tekorten hebben ervaren en of de ervaren tekorten veranderen gaandeweg de loopbaan. Tenslotte zal nagegaan worden of UM-afgestudeerden in de opleiding voldoende kennis en vaardigheden opgedaan hebben voor hun werk en voor de verdere ontwikkeling van hun competenties.

Er wordt gerapporteerd aan de hand van tabellen en figuren. In de bijlage zijn de tabellen die bij de figuren horen gepresenteerd. 


\section{Ontwikkeling van de arbeidsmarktpositie tijdens de loopbaan}

Hoe ontwikkelt de arbeidsmarktpositie van afgestudeerden van de Universiteit Maastricht zich tijdens de loopbaan?

$\mathrm{Na}$ hun studie betreden de meeste afgestudeerden van de Universiteit Maastricht de arbeidsmarkt. Hoe het hen daar is vergaan, zal in dit hoofdstuk aan de orde komen. Er wordt gerapporteerd over de arbeidsmarktpositie van cohort '89 (in 1988/89 UMafgestudeerden) tien jaar na afstuderen en over de arbeidsmarktpositie van cohort '94 (in 1993/94 UM-afgestudeerden) vijf jaar na afstuderen.

\subsection{Maatschappelijke positie}

\subsubsection{Maatschappelijke positie vijf en tien jaar na afstuderen}

Voor de meerderheid van de UM-afgestudeerden is betaald werk de belangrijkste bezigheid (zie figuur 2.1). Werkloosheid of het volgen van een studie komt vijf en tien jaar na afstuderen niet vaak voor. Tien jaar na afstuderen (cohort '89) is betaald werk als belangrijkste bezigheid minder belangrijk en de zorg voor gezin belangrijker dan vijf jaar na afstuderen (cohort '94). Dit is niet verwonderlijk aangezien er onder de UM-afgestudeerden veel vrouwen zijn (zie tabel 1.3).

Figuur 2.1

Maatschappelijke positie vijf en tien jaar na afstuderen, resp. cohort ' 94 en cohort '89

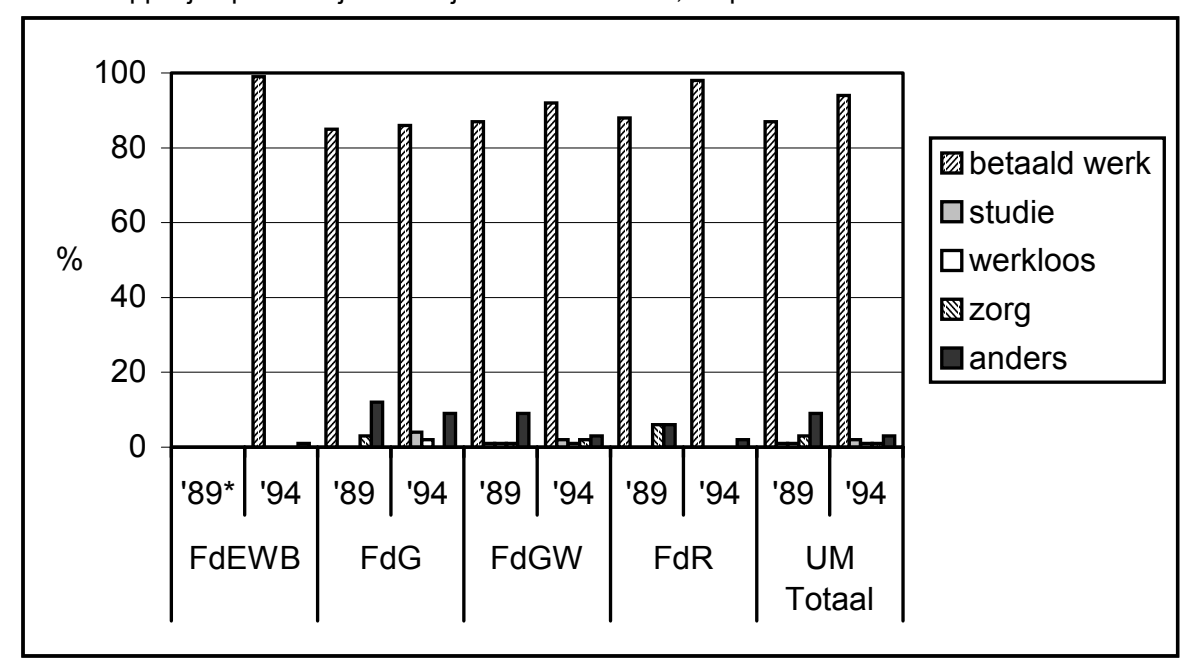

* de groep is te klein om over te rapporteren 


\subsubsection{Ontwikkeling van de maatschappelijke positie in vergelijking met het begin van de loopbaan}

Het is interessant om na te gaan hoe de maatschappelijke positie zich tijdens de loopbaan heeft ontwikkeld. Voor degenen die in studiejaar 1993/1994 afgestudeerd zijn (cohort '94) is het voor 308 van de 403 personen mogelijk om een koppeling te maken met gegevens uit de enquête van het Arbeidsmarktscanneronderzoek een jaar na afstuderen. Voor deze personen kan de maatschappelijke positie die zij een jaar na afstuderen hadden vergeleken worden met die vijf jaar na afstuderen.

In figuur 2.2 is te zien dat UM-afgestudeerden uit cohort '94 een jaar na afstuderen vrij vaak aangaven werkloos te zijn. Vooral economen en gezondheidswetenschappers waren vaak $(7 \%)$ werkloos. Dit houdt verband met de voor afgestudeerden ongunstige arbeidsmarkt in 1995. Medici hebben hier echter weinig last gehad. Dit komt waarschijnlijk doordat het artsenberoep weinig conjunctuurgevoelig is en geneeskunde een numerus fixus kent waardoor er niet snel teveel studenten worden opgeleid.

Vijf jaar na afstuderen is de werkloosheid sterk gedaald en geeft bijna niemand meer aan werkloos te zijn (1\%). In de loop van de tijd hebben de meeste afgestudeerden dus wel een baan kunnen vinden ondanks de minder gunstige arbeidsmarkt vlak na afstuderen. Opvallend is dat medici vijf jaar na afstuderen minder vaak dan de andere UM-afgestudeerden aangeven betaald werk als hun belangrijkste bezigheid te zien. Zij geven vaker aan iets anders te doen, zoals bijvoorbeeld het werken als zelfstandige.

Figuur 2.2

Maatschappelijke positie tijdens de loopbaan (één en vijf jaar na afstuderen), cohort '94

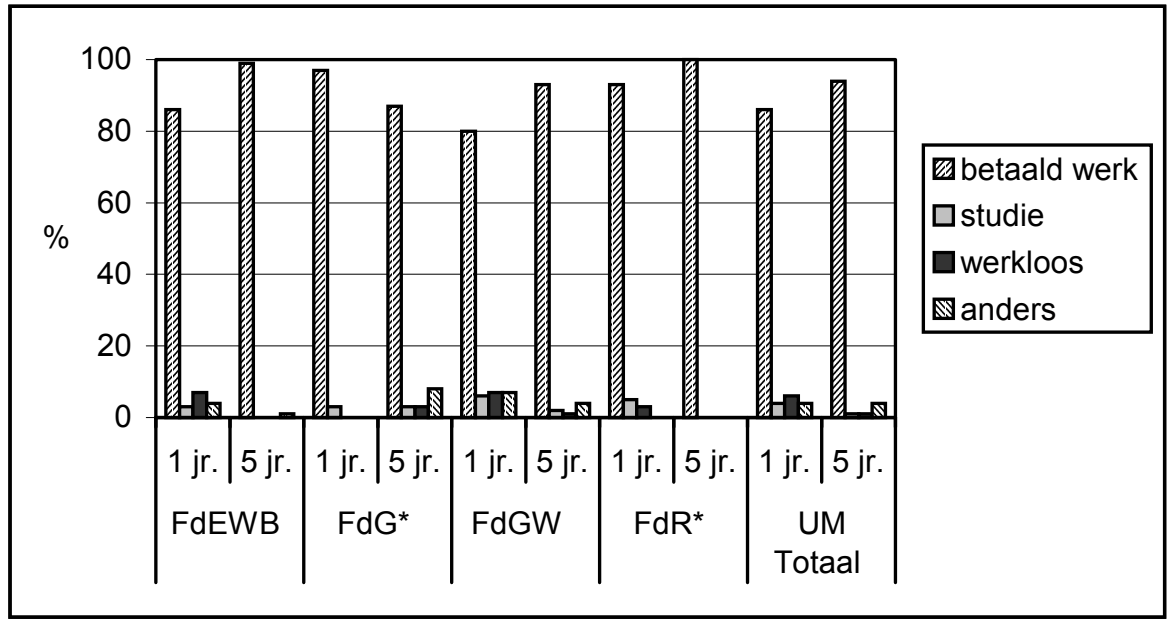

* de groep is te klein om op basis van de gepresenteerde percentages betrouwbare conclusies te kunnen trekken 
Resumerend zien we dat bij cohort ' 94 de werkloosheid tijdens de eerste vijf jaar na afstuderen sterk daalt. Tien jaar na afstuderen (cohort '89) blijkt de zorg voor het gezin belangrijker te zijn dan vijf jaar na afstuderen (cohort '94).

\subsection{Baankenmerken}

\subsubsection{Baankenmerken vijf en tien jaar na afstuderen}

\section{Vaste aanstelling}

Aan afgestudeerden is gevraagd of zij een vaste of een tijdelijke aanstelling hebben. Onder een tijdelijke aanstelling worden alle tijdelijke aanstellingen verstaan, ook degenen met uitzicht op een vaste aanstelling. In figuur 2.3 is te zien dat de meerderheid van de UM-afgestudeerden vijf en tien jaar na afstuderen een vaste aanstelling heeft. Tien jaar na afstuderen blijkt men nog iets vaker een vaste aanstelling te hebben dan vijf jaar na afstuderen. Medici hebben, vooral vijf jaar na afstuderen, vaak een tijdelijke aanstelling. Dit komt waarschijnlijk doordat zij dan vaak nog in opleiding zijn.

Figuur 2.3

Vaste aanstelling vijf en tien jaar na afstuderen, resp. cohort '94 en cohort '89

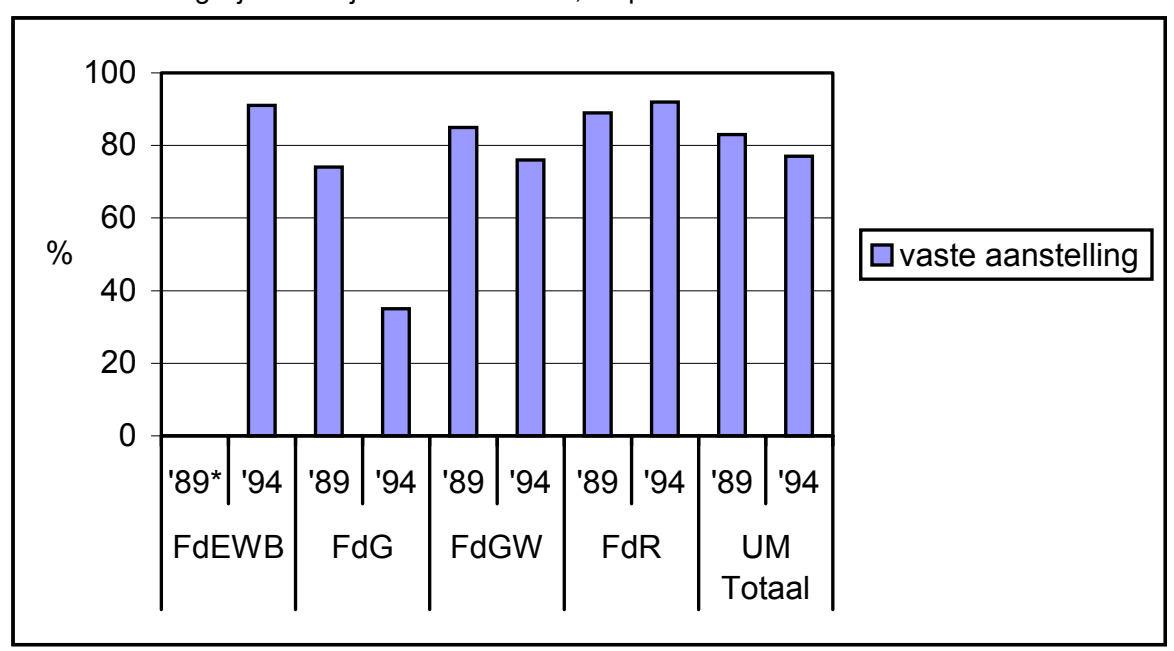

* de groep is te klein om over te rapporteren

\section{Fulltime aanstelling}

Wanneer we kijken naar het aantal uren dat men werkt (zie figuur 2.4), dan zien we dat iets minder dan driekwart van de UM-afgestudeerden fulltime (dat wil zeggen 33 uur of meer) werkt. Dit komt waarschijnlijk doordat er onder de UM-afgestudeerden veel vrouwen zijn (zie tabel 1.3) en zij vaker parttime gaan werken om werk en gezin te kunnen combineren. Tien jaar na afstuderen (cohort '89) blijkt men vaker parttime te werken dan vijf jaar na afstuderen (cohort '94). Zoals we ook al zagen in figuur 2.1 is het combineren van werk en gezin dan belangrijker. Gezondheidswetenschappers en medici werken het vaakst deeltijd. Onder hen zijn veel vrouwen die, zoals in het voorgaande al aannemelijk gemaakt werd, vaak minder gaan werken wanneer zij 
kinderen krijgen. Deze verklaring geldt echter niet voor juristen, waaronder ook veel vrouwen zijn, maar die wel vaak fulltime werken. Wellicht is een fulltime juridische baan makkelijker te combineren met een gezin.

Figuur 2.4

Fulltime aanstelling vijf en tien jaar na afstuderen, resp. cohort '94 en cohort ' 89

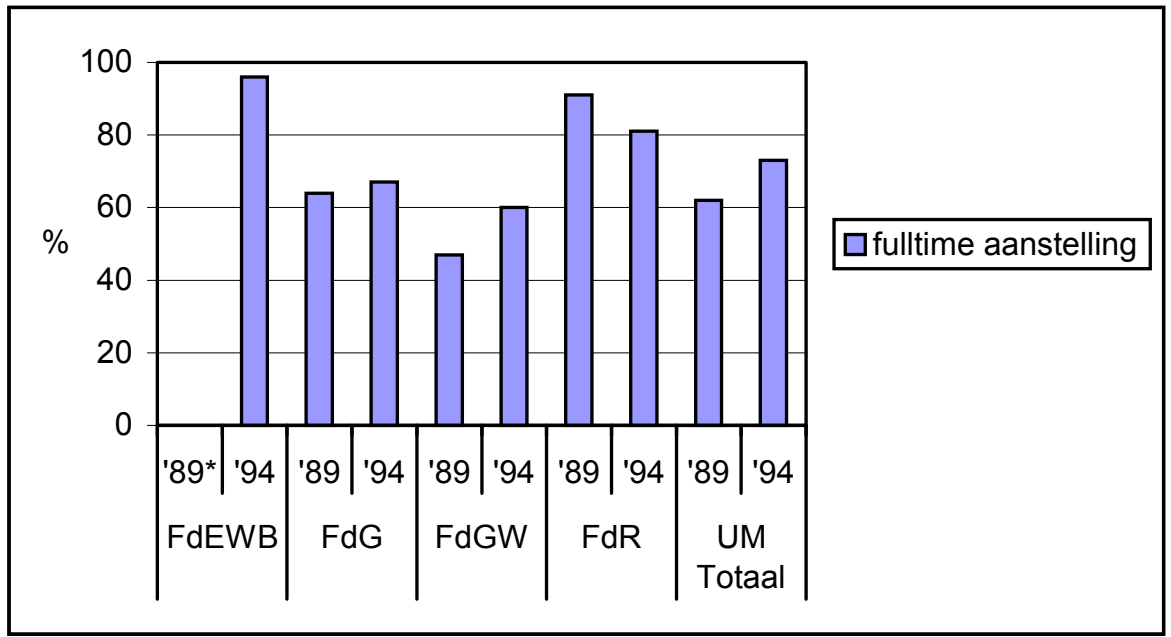

* de groep is te klein om over te rapporteren

\section{Vereiste opleidingsrichting}

De meerderheid van de UM-afgestudeerden heeft vijf en tien jaar na afstuderen een functie in de eigen of verwante richting (zie figuur 2.5). Juristen uit cohort ' 89 hebben het minst vaak een functie in hun richting. Juristen uit cohort ' 94 blijken echter wel vaak een baan te hebben in hun eigen of verwante richting.

Figuur 2.5

Vereiste opleidingsrichting vijf en tien jaar na afstuderen, resp. cohort '94 en cohort '89

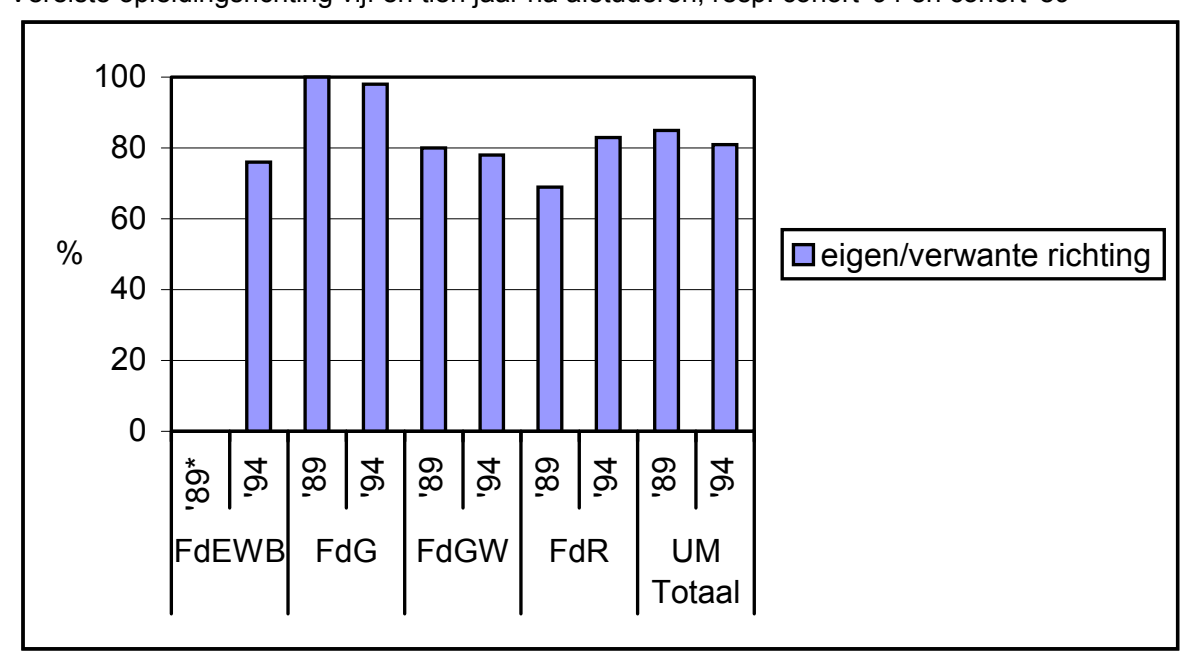

* de groep is te klein om over te rapporteren 


\section{$\underline{\text { Vereist opleidingsniveau }}$}

Het lijkt erop dat tijdens de loopbaan een stijging in het niveau van de functies te zien is (zie figuur 2.6). Tien jaar na afstuderen (cohort ' 89 ) blijkt namelijk $87 \%$ een functie te hebben waarvoor door de werkgever minimaal wo niveau is vereist, terwijl dit vijf jaar na afstuderen (cohort ' 94 ) slechts $70 \%$ betreft.

Tussen de studierichtingen zijn er redelijk grote verschillen in het niveau van de functies. Gezondheidswetenschappers en economen die vijf jaar geleden afgestudeerd zijn (cohort '94) hebben het minst vaak (minder dan driekwart) een functie op wo niveau. Tien jaar na afstuderen blijken gezondheidswetenschappers uit cohort '89 echter wel vaak een functie te hebben op wo niveau. Wellicht is de periode tussen vijf en tien jaar na afstuderen een belangrijke periode voor gezondheidswetenschappers om door te groeien naar een functie op wo niveau. Voor economen zal wellicht hetzelfde gelden, maar hier hebben we helaas geen gegevens over. In tegenstelling tot economen, gezondheidswetenschappers en juristen blijkt van de medici iedereen een functie te hebben op wo niveau. Dit komt doordat zij vaak arts of $\mathrm{AIO}$ worden en hiervoor nu eenmaal de wo opleiding geneeskunde nodig is.

Figuur 2.6

Vereist opleidingsniveau vijf en tien jaar na afstuderen, resp. cohort '94 en cohort '89

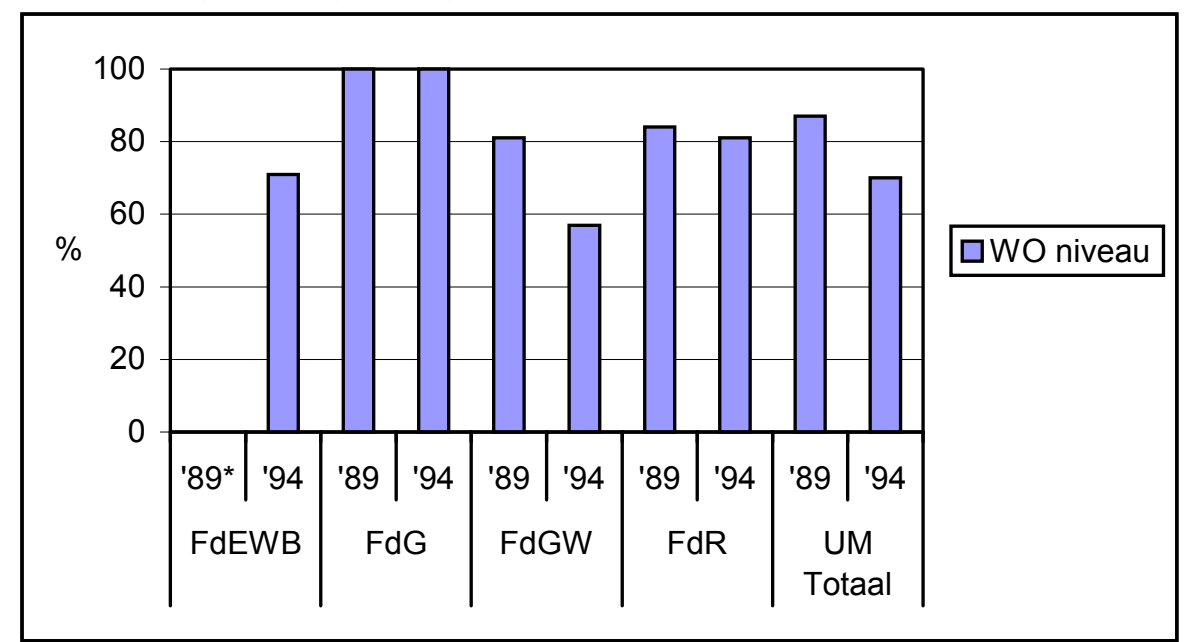

* de groep is te klein om over te rapporteren

\section{$\underline{\text { Salaris }}$}

Tien jaar na afstuderen ligt het gemiddelde bruto maandloon van UM-afgestudeerden net iets boven de FI. 7000,- (zie figuur 2.7). Dit is ongeveer FI. 1000,- meer dan zij vijf jaar na afstuderen verdienen. Wanneer we kijken naar cohort '94, dan zien we dat juristen en economen vijf jaar na afstuderen per uur het meest verdienen (zie figuur 2.8). Doordat medici echter meer (gemiddeld 40 uur) werken dan juristen (gemiddeld 37 uur), blijken medici vijf jaar na afstuderen per maand meer te verdienen dan juristen. Tien jaar na afstuderen is het inkomen van medici flink gestegen en blijken 
zij zowel per uur als per maand van alle UM-afgestudeerden het meest te verdienen. Gezondheidswetenschappers verdienen het minst van alle UM-afgestudeerden.

Figuur 2.7

Totaal bruto maandloon vijf en tien jaar na afstuderen, resp. cohort '94 en cohort '89

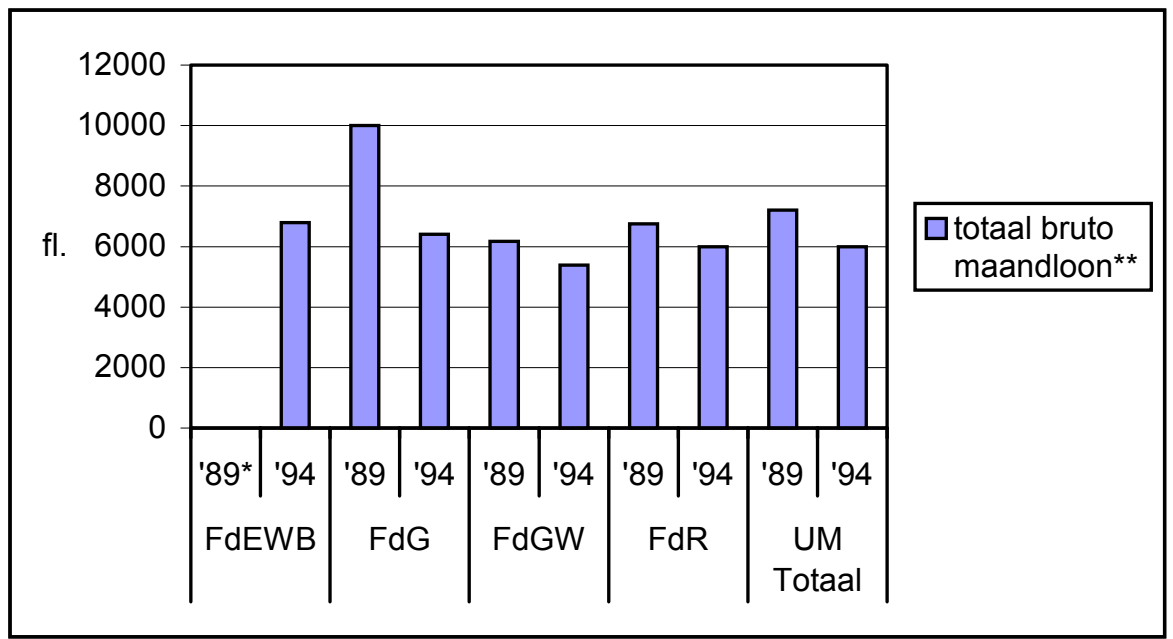

* de groep is te klein om over te rapporteren

** inclusief nevenfuncties

Figuur 2.8

Bruto uurloon vijf en tien jaar na afstuderen, resp. cohort '94 en cohort ' 89

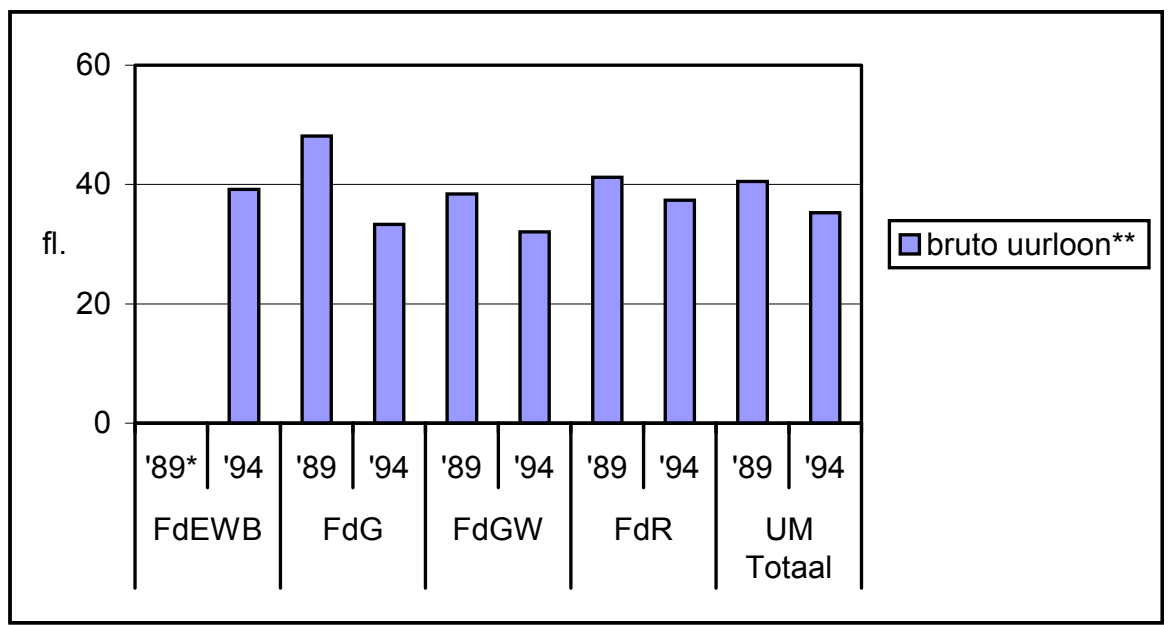

* de groep is te klein om over te rapporteren

** exclusief nevenfuncties 


\subsubsection{Ontwikkeling van baankenmerken in vergelijking met het begin van de loopbaan}

Voor degenen die in studiejaar 1993/1994 afgestudeerd zijn (cohort '94) is het voor 308 van de 403 personen mogelijk om een koppeling te maken met gegevens uit de enquête van het Arbeidsmarktscanneronderzoek een jaar na afstuderen. Voor deze personen kunnen baankenmerken een jaar na afstuderen vergeleken worden met die vijf jaar na afstuderen.

\section{Vaste aanstelling}

Minder dan de helft van de afgestudeerden uit cohort ' 94 blijkt een jaar na afstuderen een vaste aanstelling te hebben (zie figuur 2.9). Vijf jaar na afstuderen is het percentage met een vaste aanstelling flink gestegen en blijkt de meerderheid, vooral van de economen en juristen, een vaste aanstelling te hebben gekregen. Medici blijken na vijf jaar echter nog niet zo vaak een vaste aanstelling te hebben. Dit komt waarschijnlijk doordat zij dan vaak nog in opleiding zijn.

Figuur 2.9

Vaste aanstelling tijdens de loopbaan (één en vijf jaar na afstuderen), cohort '94

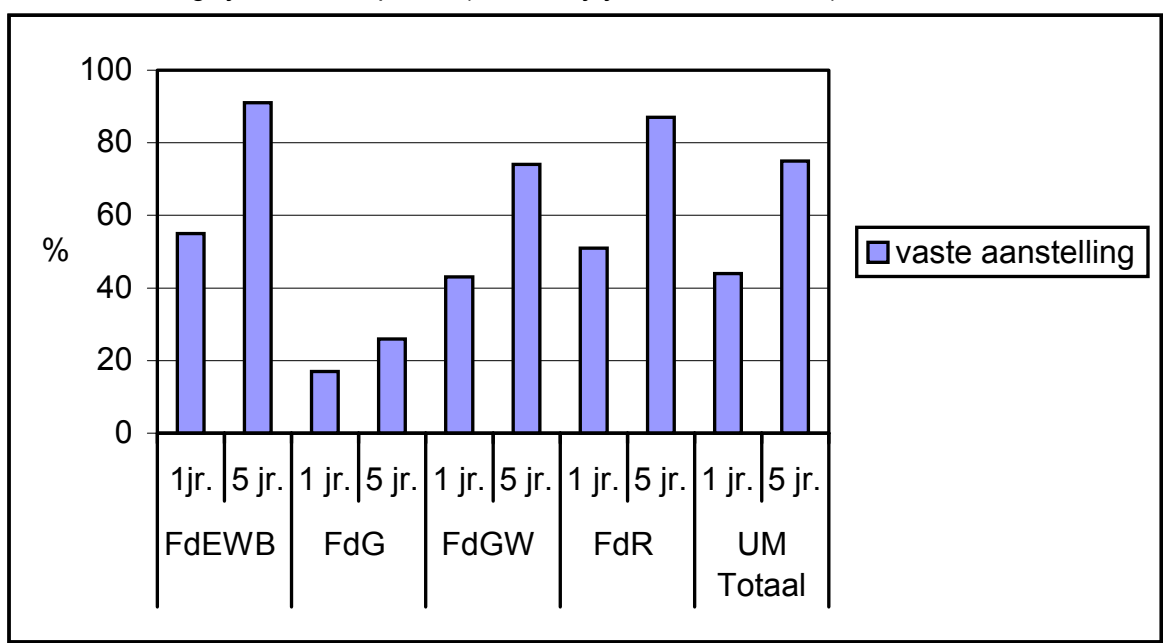

Fulltime aanstelling

Vijf jaar na afstuderen blijkt men wat vaker parttime ( $<33$ uur) te werken dan een jaar na afstuderen (zie figuur 2.10). De meerderheid blijft echter ook vijf jaar na afstuderen fulltime werken. Onder UM-afgestudeerden zijn veel vrouwen (zie tabel 1.3) voor wie parttime werken waarschijnlijk belangrijk is om werk en gezin goed te kunnen combineren. Alleen economen werken vijf jaar na afstuderen bijna allemaal fulltime. De meerderheid van hen is man (zie tabel 1.3). 
Figuur 2.10

Fulltime aanstelling tijdens de loopbaan (één en vijf jaar na afstuderen), cohort '94

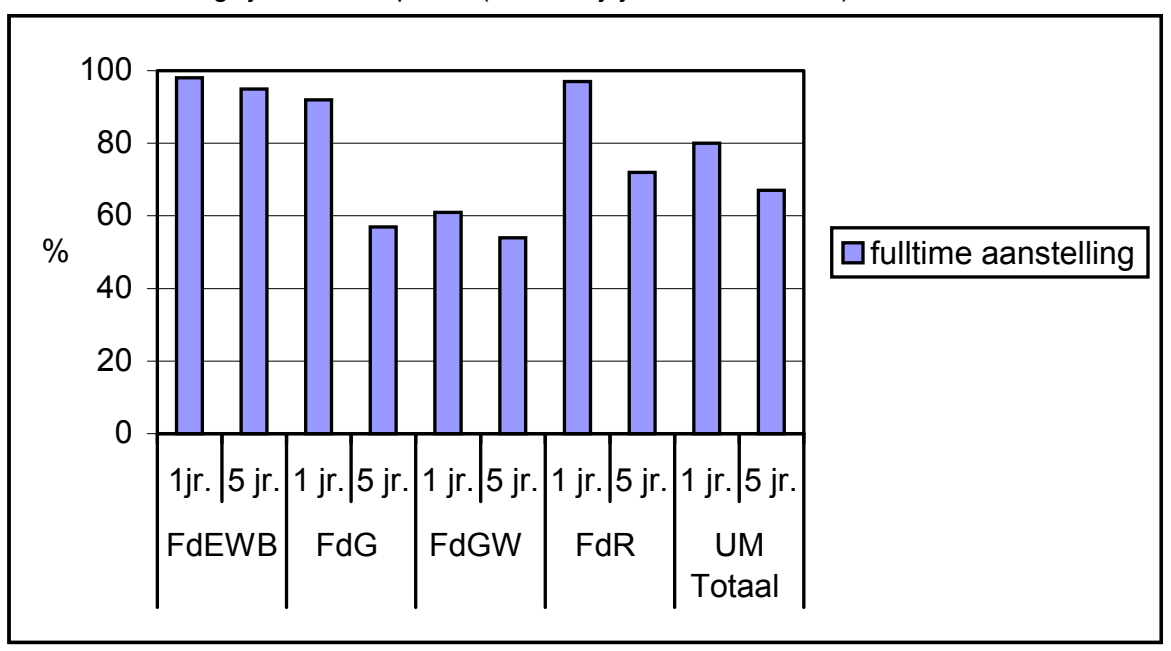

\section{Vereiste opleidingsrichting}

Wat betreft de voor de functie vereiste opleidingsrichting is nauwelijks een ontwikkeling te zien in de loop van de tijd (zie figuur 2.11). Een en vijf jaar na afstuderen blijkt de meerderheid in zijn eigen of een verwante richting te werken.

Figuur 2.11

Vereiste opleidingsrichting tijdens de loopbaan (één en vijf jaar na afstuderen), cohort '94

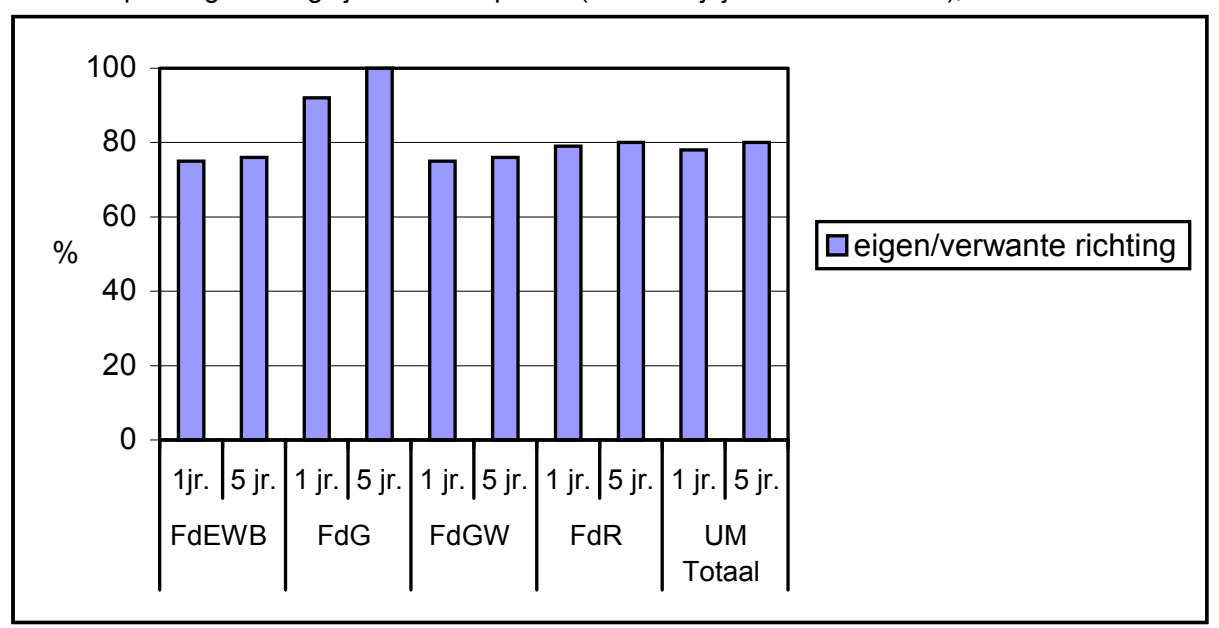

\section{Vereist opleidingsniveau}

Vijf jaar na afstuderen hebben met name economen en in mindere mate ook gezondheidswetenschappers een stijging doorgemaakt in het voor de functie vereiste opleidingsniveau (zie figuur 2.12). Een jaar na afstuderen bleek slechts $42 \%$ van de gezondheidswetenschappers en $53 \%$ van de economen een functie te hebben op wo niveau, terwijl vijf jaar na afstuderen $58 \%$ van de gezondheidswetenschappers en 
$73 \%$ van de economen een functie heeft op wo niveau. Het baanniveau van medici en juristen is in de loop der jaren nagenoeg hetzelfde gebleven.

Figuur 2.12

Vereist opleidingsniveau tijdens de loopbaan (één en vijf jaar na afstuderen), cohort '94

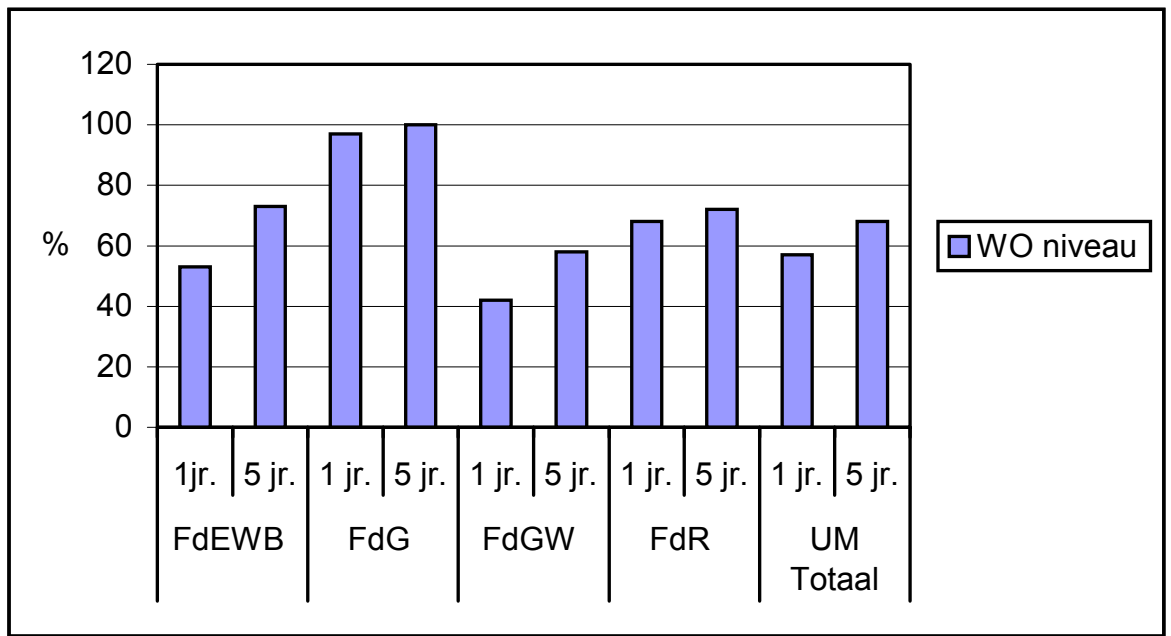

\section{Salaris}

De lonen blijken vijf jaar na afstuderen flink te zijn gestegen in vergelijking tot een jaar na afstuderen (zie figuur 2.13 en figuur 2.14). Hierbij is gecorrigeerd voor inflatie (zie voetnoot tabel). Een jaar na afstuderen verdiende men namelijk gemiddeld FI. 3.770,- bruto per maand, terwijl men vijf jaar na afstuderen FI. 5.502,- per maand verdient.

Het inkomen van economen is in de vijf jaar na afstuderen het snelst gestegen. Een jaar na afstuderen verdienen zij namelijk 'slechts' FI. 21,63 per uur en FI. 3.750,- per maand, terwijl dit vijf jaar na afstuderen FI. 35,82 per uur is en FI. 6.210,- per maand. Medici verdienen een jaar na afstuderen het meest. Hun salaris blijkt echter het minst hard te stijgen, waardoor zij vijf jaar na afstuderen per uur ongeveer evenveel verdienen als gezondheidswetenschappers en juristen en minder dan economen. Dit zou kunnen komen doordat medici vijf jaar na afstuderen vaak nog in opleiding zijn. $\mathrm{Na}$ afloop van hun vervolgopleiding blijkt het inkomen van medici nog sterk te stijgen. Het salaris van medici ligt tien jaar na afstuderen namelijk een stuk hoger dan vijf jaar na afstuderen (zie figuur 2.7 en figuur 2.8). 
Figuur 2.13

Totaal bruto maandinkomen tijdens de loopbaan (één en vijf jaar na afstuderen), cohort '94*

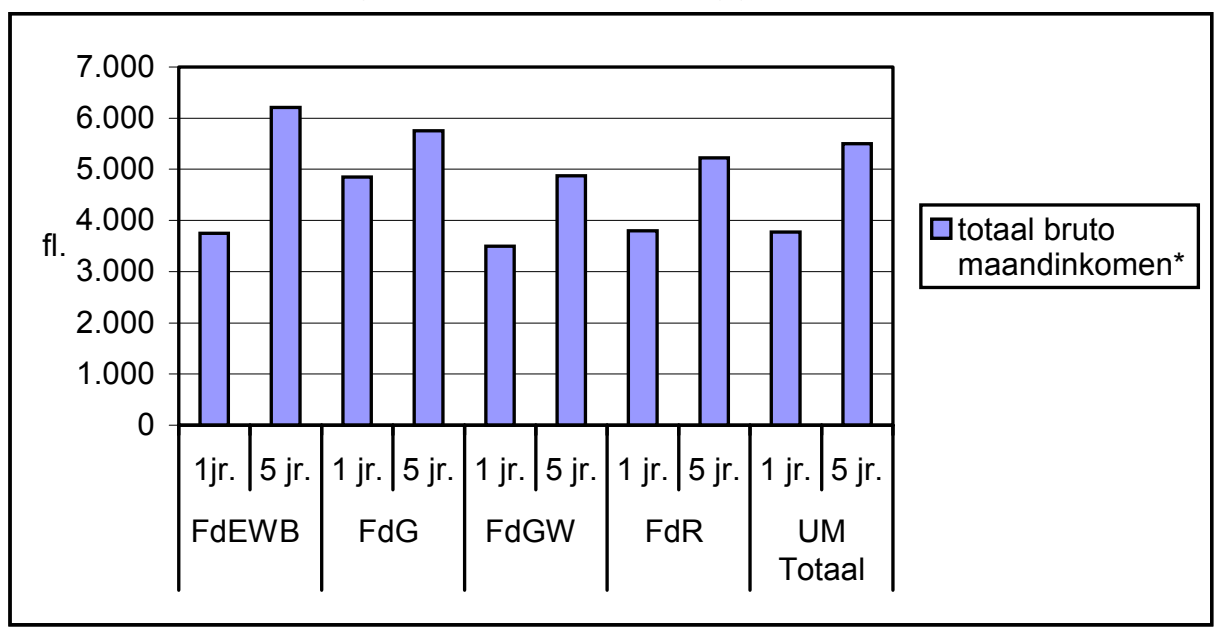

* Inclusief nevenfuncties. Er is gecorrigeerd voor inflatie op basis van de prijsindexcijfers van het CBS. De prijsindex voor 1990 is op 100 gesteld. In meetjaar 1995 ( 1 jr. na afstuderen) was de prijsindex 114 en in 1999 (5 jr. na afstuderen) 124. Om de lonen in 1999 vergelijkbaar te maken met die van 1995 zijn de lonen in 1999 vermenigvuldigd met $114 / 124=0.92$.

Figuur 2.14

Bruto uurloon tijdens de loopbaan (één en vijf jaar na afstuderen), cohort ' 94 *

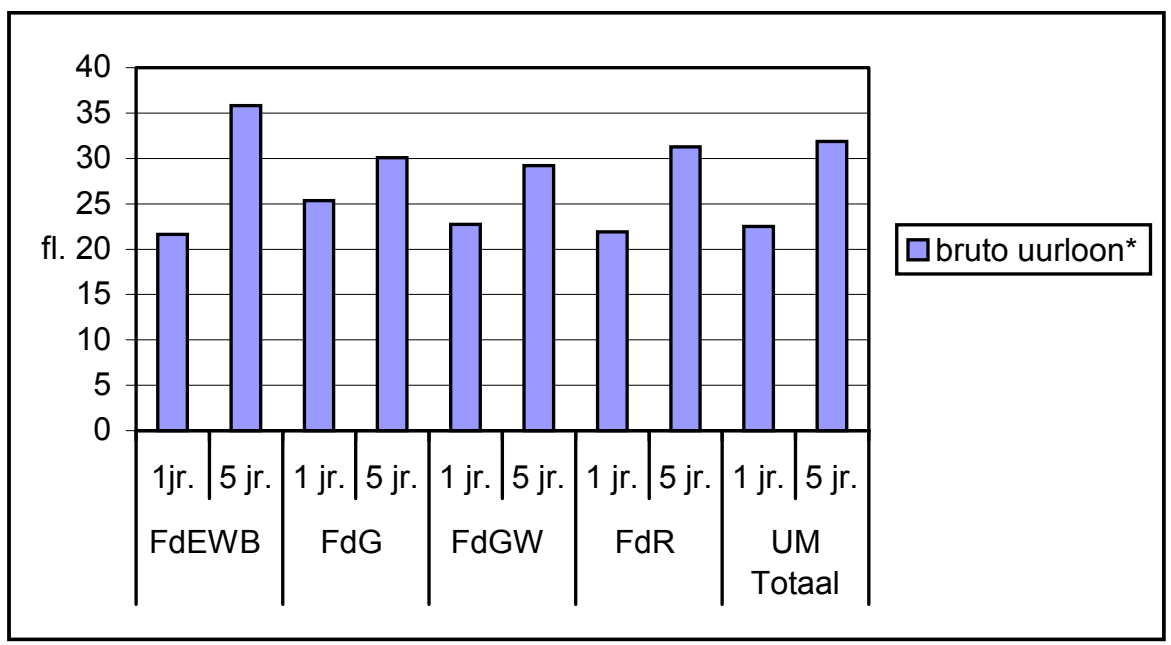

* Exclusief nevenfuncties. Er is gecorrigeerd voor inflatie op basis van de prijsindexcijfers van het CBS. De prijsindex voor 1990 is op 100 gesteld. In meetjaar 1995 (1 jr. na afstuderen) was de prijsindex 114 en in 1999 (5 jr na afstuderen) 124. Om de lonen in 1999 vergelijkbaar te maken met die van 1995 zijn de lonen in 1999 vermenigvuldigd met $114 / 124=0.92$.

Resumerend zien we dat UM-afgestudeerden, gaandeweg de loopbaan vaker een vaste aanstelling krijgen, minder vaak fulltime gaan werken, vaker een functie op wo niveau krijgen en meer gaan verdienen. 


\subsection{Vervolgopleiding}

$\mathrm{Na}$ een academische studie is het niet voor iedereen afgelopen met leren. In tabel 2.1 is namelijk te zien dat een groot deel van de UM-afgestudeerden na afstuderen nog een vervolgopleiding volgt. Van cohort ' 89 heeft zelfs meer dan de helft na afstuderen nog een vervolgopleiding gedaan.

Van alle UM-afgestudeerden blijken medici het vaakst nog een vervolgopleiding te volgen. Dit is niet verwonderlijk, aangezien zij een postdoctorale beroepsopleiding nodig hebben om huisarts, sociaal geneeskundige of specialist te kunnen worden. Economen en juristen uit cohort ' 94 volgen het minst vaak nog een vervolgopleiding.

De meerderheid volgt zijn vervolgopleiding voltijds. Economen zijn de enige die hun vervolgopleiding voornamelijk in deeltijd volgen. Dit komt waarschijnlijk doordat zij vaak een postdoctorale beroepsopleiding accountancy volgen, die alleen in deeltijd gegeven wordt.

Vijf jaar na afstuderen heeft ongeveer de helft zijn vervolgopleiding voltooid. Vooral medici en gezondheidswetenschappers zijn dan nog vaak bezig met hun vervolgopleiding. Tien jaar na afstuderen is het merendeel, ook van de medici en de gezondheidswetenschappers, klaar met hun vervolgopleiding. Voortijdig verlaten van de vervolgopleiding komt niet vaak (bij ongeveer een tiende deel) voor.

Tabel 2.1

Vervolgopleiding vijf en tien jaar na afstuderen, resp. cohort '94 en cohort '89

\begin{tabular}{|c|c|c|c|c|c|c|c|c|c|c|}
\hline \multirow[b]{2}{*}{ Cohort: } & \multicolumn{2}{|c|}{ FdEWB } & \multicolumn{2}{|c|}{$\mathrm{FdG}$} & \multicolumn{2}{|c|}{ FdGW } & \multicolumn{2}{|c|}{$\mathrm{FdR}$} & \multicolumn{2}{|c|}{ UM Totaal } \\
\hline & $\begin{array}{r}89 \\
\%\end{array}$ & $\begin{array}{r}94 \\
\%\end{array}$ & $\begin{array}{r}89 \\
\%\end{array}$ & $\begin{array}{r}94 \\
\%\end{array}$ & $\begin{array}{r}89 \\
\%\end{array}$ & $\begin{array}{r}' 94 \\
\%\end{array}$ & $\begin{array}{r}89 \\
\%\end{array}$ & $\begin{array}{r}' 94 \\
\%\end{array}$ & $\begin{array}{r}89 \\
\%\end{array}$ & $\begin{array}{r}' 94 \\
\%\end{array}$ \\
\hline $\begin{array}{l}\text { Vervolgopleiding } \\
\text { gevolgd }\end{array}$ & - & 31 & 95 & 87 & 44 & 34 & 54 & 21 & 64 & 38 \\
\hline $\begin{array}{l}\text { Voltijd } \\
\text { vervolgopleiding }\end{array}$ & - & 25 & 73 & 83 & 54 & 53 & - & - & 65 & 57 \\
\hline $\begin{array}{l}\text { Vervolgopleiding: } \\
\text { Voltooid } \\
\text { Nog bezig } \\
\text { Voortijdig } \\
\text { verlaten }\end{array}$ & - & $\begin{array}{l}70 \\
19 \\
11\end{array}$ & $\begin{array}{r}84 \\
11 \\
\\
5\end{array}$ & $\begin{array}{r}39 \\
53 \\
8\end{array}$ & $\begin{array}{r}86 \\
6\end{array}$ & $\begin{array}{r}53 \\
38 \\
9\end{array}$ & - & - & $\begin{array}{r}82 \\
7\end{array}$ & $\begin{array}{l}54 \\
37 \\
10\end{array}$ \\
\hline
\end{tabular}

'-' de groep is te klein om over te rapporteren

\subsection{Buitenlandervaring}

Door ontwikkelingen op het gebied van informatie- en communicatietechnologie worden de afstanden tussen landen steeds kleiner. Het buitenland komt dichterbij. UM-afgestudeerden kunnen makkelijker in het buitenland gaan werken en krijgen 
sneller met het buitenland te maken voor hun werk in Nederland. Het werken of studeren in een ander land (oftewel buitenlandervaring) kan belangrijk zijn om hen hierop voor te bereiden.

In deze paragraaf gaan we na hoe vaak UM-afgestudeerden buitenlandervaring opdoen en hoe vaak zij met het buitenland te maken krijgen voor hun werk (zie tabel 2.2).

\section{Opdoen van buitenlandervaring}

Tijdens de opleiding blijkt ongeveer een derde deel van de UM-afgestudeerden buitenlandervaring te hebben opgedaan. Economen zijn tijdens hun opleiding het vaakst in het buitenland geweest en gezondheidswetenschappers het minst vaak. Voorafgaand aan de opleiding heeft men niet vaak (ongeveer een tiende deel) buitenlandervaring opgedaan.

\section{Werk in buitenland}

Zo'n $30 \%$ van de UM-afgestudeerden blijkt overwogen te hebben om in het buitenland te gaan werken. Men heeft echter niet vaak (iets meer dan een tiende van alle UM-afgestudeerden) werk in het buitenland gezocht of in het buitenland gewerkt. Wel blijkt een redelijk groot deel van de UM-afgestudeerden (30\%) naar het buitenland te reizen voor het werk. Economen blijken het vaakst naar het buitenland te reizen.

\section{Tabel 2.2}

Buitenlandervaring vijf en tien jaar na afstuderen, resp. cohort ' 94 en cohort '89

\begin{tabular}{|c|c|c|c|c|c|c|c|c|c|c|}
\hline \multirow[b]{2}{*}{ Cohort: } & \multicolumn{2}{|c|}{ FdEWB } & \multicolumn{2}{|c|}{ FdG } & \multicolumn{2}{|c|}{ FdGW } & \multicolumn{2}{|c|}{ FdR } & \multicolumn{2}{|c|}{ UM Totaal } \\
\hline & $\begin{array}{r}89 \\
\%\end{array}$ & $\begin{array}{r}' 94 \\
\%\end{array}$ & $\begin{array}{r}89 \\
\%\end{array}$ & $\begin{array}{r}94 \\
\%\end{array}$ & $\begin{array}{r}89 \\
\%\end{array}$ & $\begin{array}{r}' 94 \\
\%\end{array}$ & $\begin{array}{r}89 \\
\%\end{array}$ & $\begin{array}{r}' 94 \\
\%\end{array}$ & $\begin{array}{r}89 \\
\%\end{array}$ & $\begin{array}{r}94 \\
\%\end{array}$ \\
\hline Buitenlandervaring & & & & & & & & & & \\
\hline voor de opleiding & - & 8 & 18 & 6 & 4 & 8 & 14 & 19 & 10 & 10 \\
\hline $\begin{array}{l}\text { Buitenlandervaring } \\
\text { tijdens de opleiding }\end{array}$ & - & 52 & 39 & 44 & 16 & 21 & 34 & 30 & 27 & 33 \\
\hline Werk in buitenland: & & & & & & & & & & \\
\hline Overwogen & - & 40 & 43 & 30 & 27 & 28 & 43 & 28 & 37 & 31 \\
\hline $\begin{array}{l}\text { Gezocht } \\
\text { Aanqeboden }\end{array}$ & - & 14 & 15 & 14 & 12 & 8 & 11 & 6 & 13 & 10 \\
\hline Gekregen & - & 15 & 13 & 7 & 11 & 6 & 0 & 3 & 9 & 8 \\
\hline Gehad & - & 22 & 16 & 7 & 20 & 7 & 3 & 11 & 15 & 11 \\
\hline $\begin{array}{l}\text { Buitenlandse } \\
\text { reizen in kader van } \\
\text { werk }\end{array}$ & - & 51 & 30 & 36 & 35 & 24 & 20 & 16 & 30 & 30 \\
\hline
\end{tabular}

'-' de groep is te klein om over te rapporteren 


\subsection{Conclusie}

Wanneer we kijken naar de loopbanen van UM-afgestudeerden, dan zien we dat men gaandeweg de loopbaan vaker een vaste aanstelling krijgt, minder vaak fulltime gaat werken, vaker alsnog een functie op wo niveau krijgt en meer gaat verdienen. Gaandeweg de loopbaan blijkt een combinatie van werk en gezin belangrijker te worden. $\mathrm{Na}$ afstuderen blijkt een groot deel van de afgestudeerden nog een vervolgopleiding te volgen. lets minder dan een derde van de UM-afgestudeerden reist voor het werk wel eens naar het buitenland. 



\title{
3 Werkrelevante competenties
}

\author{
Welke competenties zijn belangrijk in het werk van afgestudeerden van de \\ Universiteit Maastricht? \\ In dit hoofdstuk gaan we wat meer inhoudelijk naar het werk van UM-afgestudeerden \\ kijken. We gaan na welke kennis, vaardigheden en houdingsaspecten oftewel welke \\ competenties belangrijk zijn in hun werk en we bekijken of dit tijdens de loopbaan \\ verandert. Met deze informatie kunnen opleidingen hun voordeel doen. Het onderwijs \\ zou zich dan namelijk kunnen richten op een goede beheersing van de competenties \\ die studenten later in hun werk nodig hebben. Dit zou ervoor kunnen zorgen dat \\ studenten beter voorbereid op de arbeidsmarkt terechtkomen.
}

\subsection{Gebruik van competenties vijf en tien jaar na afstuderen}

Om erachter te komen welke competenties (kennis, vaardigheden, houdingsaspecten) belangrijk zijn voor het werk van UM-afgestudeerden, zal in de eerste plaats bekeken worden hoe vaak UM-afgestudeerden bepaalde competenties gebruiken in hun werk. Aan de UM-afgestudeerden uit cohort '89 en '94 is gevraagd in welke mate zij een aantal competenties gebruiken in hun werk. Hierbij konden zij antwoorden op een schaal van 1 'niet' tot en met 5 'in hoge mate'. In tabel 3.1 wordt het percentage gepresenteerd dat aangeeft de betreffende competentie (redelijk) intensief (antwoordcategorie 4 of 5 ) te gebruiken.

Zelfstandigheid en communicatieve vaardigheden blijken zeer belangrijke competenties te zijn in het werk van UM-afgestudeerden. In bijna alle banen worden deze competenties intensief gebruikt. Initiatief, plannen en organiseren, omgaan met- en inspelen op veranderingen, nauwkeurigheid, werken in teamverband en vakkennis worden ook door meer dan driekwart van de UM-afgestudeerden gebruikt. Internationale oriëntatie, met cijfers om kunnen gaan en leidinggeven zijn minder belangrijke competenties. Dit zijn vrij specifieke competenties die in redelijk veel banen niet of nauwelijks gebruikt worden.

Wanneer we kijken naar verschillen tussen studierichtingen, dan zien we dat omgaan met cijfers, computergebruik, internationale oriëntatie en leidinggeven relatief belangrijk zijn voor economen. Nauwkeurigheid is voor economen minder belangrijk dan voor andere UM-afgestudeerden.

Voor medici is vakkennis en vakspecifieke methoden en technieken relatief vaak belangrijk. Verder dienen zij vaker nauwkeurig te zijn dan andere UM-afgestudeerden. Ook blijken medici (net als economen) vaak leiding te geven. Het zal hierbij waarschijnlijk gaan om leidinggeven aan verplegend personeel en aan andere medici die nog in opleiding zijn, zoals bijvoorbeeld co-assistenten. Computergebruik en met cijfers omgaan is voor medici minder belangrijk dan voor andere UMafgestudeerden. 
Wat opvalt bij juristen is de bevinding, dat zij minder vaak in teamverband werken en minder vaak leidinggeven. Zij zullen waarschijnlijk vaker 'solo-functies' hebben.

De banen van gezondheidswetenschappers blijken moeilijker te karakteriseren te zijn qua competenties, aangezien er bij hen geen competenties aan te wijzen zijn die zij juist veel meer of veel minder gebruiken dan de afgestudeerden uit de andere richtingen. Gezondheidswetenschappen is een studie met veel verschillende afstudeerrichtingen die dus mensen opleidt voor een heel scala van functies.

Tabel 3.1

Gebruik van competenties vijf en tien jaar na afstuderen (\% (redelijk) vaak), resp. cohort ' 94 en cohort ' 89

\begin{tabular}{|c|c|c|c|c|c|c|c|c|c|c|}
\hline \multirow[b]{2}{*}{ Cohort: } & \multicolumn{2}{|c|}{ FdEWB } & \multicolumn{2}{|c|}{ FdG } & \multicolumn{2}{|c|}{ FdGW } & \multicolumn{2}{|c|}{ FdR } & \multicolumn{2}{|c|}{ UM Totaal } \\
\hline & $\begin{array}{r}89 \\
\%\end{array}$ & $\begin{array}{r}' 94 \\
\%\end{array}$ & $\begin{array}{r}\text { '89 } \\
\%\end{array}$ & $\begin{array}{r}94 \\
\%\end{array}$ & $\begin{array}{r}89 \\
\%\end{array}$ & $\begin{array}{r}' 94 \\
\%\end{array}$ & $\begin{array}{r}' 89 \\
\%\end{array}$ & $\begin{array}{r}94 \\
\%\end{array}$ & $\begin{array}{r}' 89 \\
\%\end{array}$ & $\begin{array}{r}' 94 \\
\%\end{array}$ \\
\hline $\begin{array}{l}\text { Vakkennis } \\
\text { Vakspecifieke } \\
\text { methoden en }\end{array}$ & - & 76 & 94 & 94 & 75 & 74 & 66 & 84 & 79 & 79 \\
\hline technieken & - & 64 & 89 & 94 & 56 & 63 & 53 & 68 & 66 & 69 \\
\hline $\begin{array}{l}\text { Computergebruik } \\
\text { Met cijfers om }\end{array}$ & - & 83 & 59 & 40 & 65 & 74 & 78 & 62 & 67 & 70 \\
\hline $\begin{array}{l}\text { kunnen gaan } \\
\text { Communicatieve }\end{array}$ & - & 77 & 18 & 21 & 42 & 48 & 30 & 35 & 33 & 49 \\
\hline $\begin{array}{l}\text { vaardigheden } \\
\text { Werken in }\end{array}$ & - & 98 & 96 & 100 & 91 & 97 & 94 & 95 & 94 & 97 \\
\hline $\begin{array}{l}\text { teamverband } \\
\text { Plannen en }\end{array}$ & - & 89 & 89 & 85 & 87 & 79 & 64 & 60 & 83 & 79 \\
\hline organiseren & - & 84 & 82 & 81 & 83 & 90 & 84 & 80 & 83 & 86 \\
\hline Leidinggeven & - & 50 & 59 & 46 & 44 & 33 & 30 & 33 & 46 & 39 \\
\hline Zelfstandigheid & - & 94 & 100 & 96 & 95 & 96 & 100 & 95 & 98 & 96 \\
\hline Creativiteit & - & 67 & 79 & 67 & 71 & 70 & 70 & 78 & 72 & 70 \\
\hline $\begin{array}{l}\text { Initiatief } \\
\text { Omgaan met en } \\
\text { inspelen op }\end{array}$ & - & 82 & 86 & 81 & 89 & 89 & 85 & 89 & 87 & 86 \\
\hline veranderingen & - & 83 & 82 & 78 & 81 & 82 & 82 & 80 & 81 & 82 \\
\hline $\begin{array}{l}\text { Nauwkeurigheid } \\
\text { Internationale }\end{array}$ & - & 70 & 91 & 90 & 72 & 82 & 79 & 86 & 80 & 81 \\
\hline oriëntatie & - & 39 & 20 & 8 & 17 & 17 & 30 & 26 & 20 & 23 \\
\hline
\end{tabular}

'-' de groep is te klein om over te rapporteren

\subsection{Vereist niveau van competenties vijf en tien jaar na afstuderen}

Tabel 3.2 laat zien hoe vaak een uitmuntende beheersing van bepaalde competenties vereist is voor het werk van UM-afgestudeerden.

Voor de competenties die in paragraaf 3.1 als belangrijkste naar voren kwamen is vaak ook een hoog niveau van beheersing vereist. Zo is uitmuntend zelfstandig werken en het beschikken over uitstekende communicatieve vaardigheden voor relatief veel banen van UM-afgestudeerden (iets minder dan de helft) vereist. Ook 
initiatief, plannen en organiseren, omgaan met- en inspelen op veranderingen, nauwkeurigheid, werken in teamverband en vakspecifieke kennis en vaardigheden dienen relatief vaak (door ongeveer een vijfde deel van de UM-afgestudeerden) op uitmuntend niveau beheerst te worden. Een zeer goede beheersing van de minder gebruikte competenties, namelijk internationale oriëntatie, met cijfers omgaan en leidinggeven is voor UM-afgestudeerden minder vaak vereist. Opvallend is het dat computergebruik slechts door 7 à $8 \%$ uitmuntend beheerst dient te worden, terwijl wel een groot deel (zo'n 70\%) met de computer werkt (zie tabel 3.1). Blijkbaar wordt de computer eerder als hulpmiddel gebruikt en is het niet zo belangrijk om op uitmuntend niveau met de computer om te kunnen gaan.

Wanneer we kijken naar verschillen tussen de studierichtingen, dan zien we dat economen de voor hen relatief belangrijke competenties, namelijk met cijfers omgaan, computergebruik en internationale oriëntatie, ook relatief vaak uitmuntend dienen te beheersen. Dit geldt echter niet voor leidinggeven. Economen hoeven namelijk niet vaker op hoog niveau leiding te geven dan andere UM-afgestudeerden.

In de banen van medici is het op hoog niveau beheersen van vakkennis, vakspecifieke methoden en technieken en nauwkeurigheid vaak vereist. Plannen en organiseren en leidinggeven hoeven medici wat minder vaak op hoog niveau te kunnen dan andere UM-afgestudeerden. Deze competenties behoren waarschijnlijk niet tot de kerntaken van een arts, maar zijn waarschijnlijk eerder voorwaardescheppend.

Net als voor medici is voor juristen een zeer goede beheersing van vakkennis, vakspecifieke methoden en technieken en nauwkeurigheid vaak belangrijk. Het op hoog niveau beheersen van communicatieve vaardigheden en werken in teamverband is voor de banen van juristen minder vaak vereist. In de vorige paragraaf zagen we al dat juristen waarschijnlijk vaak in 'solo-functies' werkzaam zullen zijn. Juristen uit cohort '94 dienen namelijk ook vaker zeer zelfstandig en creatief te zijn in hun werk. Voor juristen uit cohort '89 geldt dit echter niet. Zij dienen vakkennis en vakspecifieke methoden en technieken ook minder vaak op een zeer hoog niveau te beheersen dan juristen uit cohort '94. Deze verschillen tussen de cohorten zouden verklaard kunnen worden doordat juristen uit cohort '89 vaker dan juristen uit cohort ' 94 werkzaam zijn buiten de eigen of verwante richting (zie figuur 2.5).

Wanneer we kijken naar de banen van gezondheidswetenschappers, dan valt op dat voor hun banen het op hoog niveau beheersen van vakkennis en vakspecifieke methoden en technieken minder vaak belangrijk is. Dit is niet verwonderlijk aangezien gezondheidswetenschappen geen vakspecifieke opleiding is, waarbij de nadruk ligt op verwerving van kennis en methoden en technieken in één bepaald vakgebied, maar eerder een veldspecifieke opleiding gericht op de verwerving van multidisciplinaire kennis rondom één thema, namelijk gezondheid. Voor nadere informatie over het onderscheid tussen vak- en veldspecifieke opleidingen, verwijs ik 
naar De Wolf (2000) $)^{1}$ en Allen et al. (2001) ${ }^{2}$. In de functies van gezondheidswetenschappers is daarentegen het op uitmuntend niveau beheersen van meer generieke of algemene vaardigheden zoals het werken in teamverband en plannen en organiseren vaker belangrijk dan voor de andere UM-afgestudeerden.

Tabel 3.2

Vereist niveau van competenties (\% uitmuntend) vijf en tien jaar na afstuderen, resp. cohort '94 en cohort ' 89

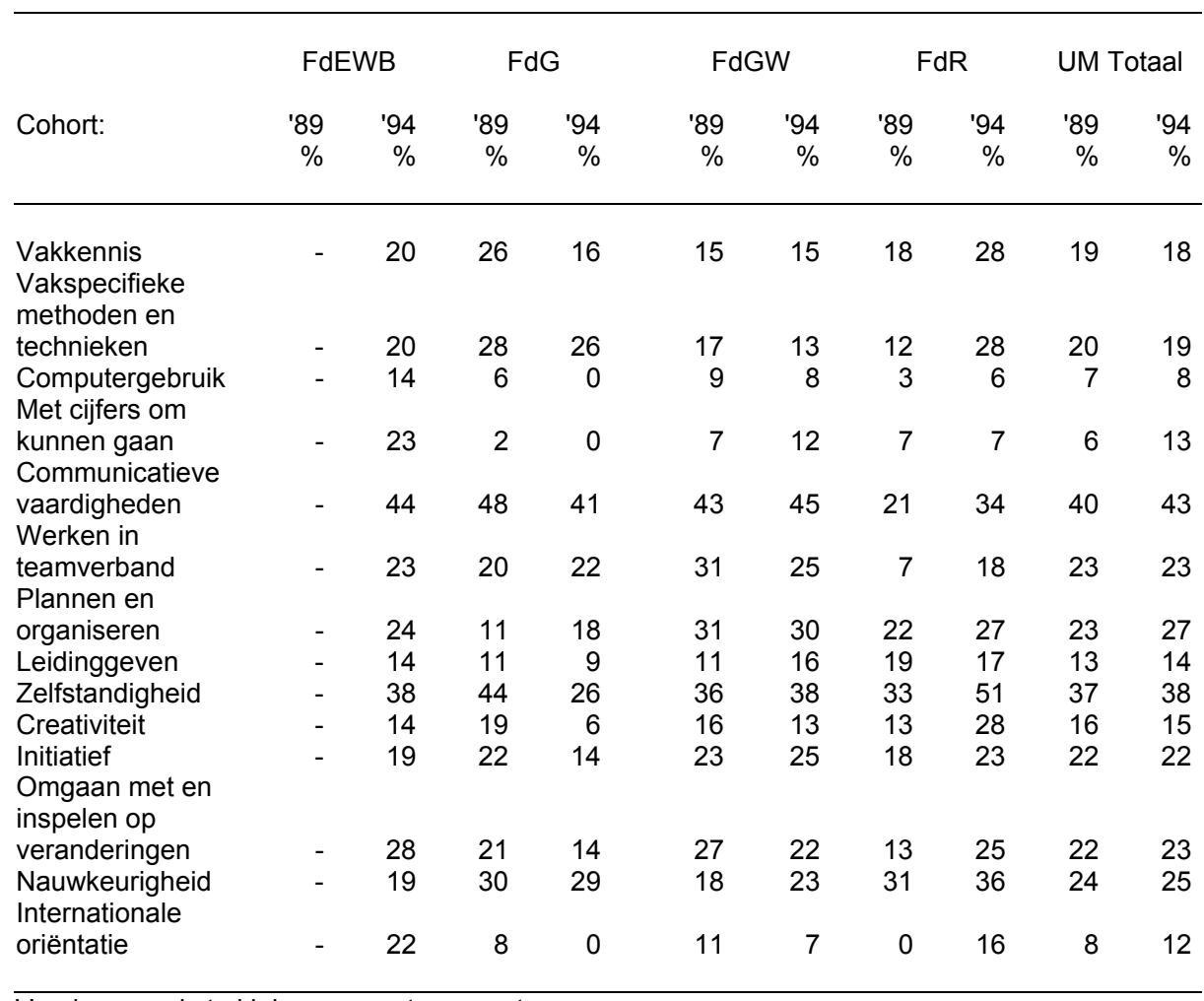

-' de groep is te klein om over te rapporteren

\subsection{Relevantie van competenties in vergelijking met het begin van de loopbaan}

Voor degenen die in studiejaar 1993/1994 afgestudeerd zijn (cohort '94) is een koppeling mogelijk met gegevens uit de enquête van de Arbeidsmarktscanner een jaar na afstuderen. Voor 308 van de 403 personen, die aan beide metingen meegedaan hebben (zie tabel 1.2), kunnen we bekijken of bepaalde competenties

1. Wolf, I. de (2000), Opleidingsspecialisatie en arbeidsmarktsucces van sociale wetenschappers. Dissertatie, Universiteit Utrecht.

2. Allen, J., Eijs, P. van, T. Huijgen, G. Ramaekers, R. van der Velden, F. Verbeek en R. de Vries (2001), Academici op de arbeidsmarkt. De arbeidsmarktpositie van afgestudeerden van de Nederlandse universiteiten, afstudeerjaar 1997-1998, VSNU. 
vijf jaar na afstuderen belangrijker dan wel minder belangrijk zijn geworden dan een jaar na afstuderen.

De vraagstelling was in beide enquêtes echter niet gelijk. In de enquête een jaar na afstuderen is namelijk gevraagd hoe belangrijk bepaalde competenties voor een goede uitoefening van een functie zijn, terwijl in de enquête vijf jaar na afstuderen gevraagd is naar de mate waarin bepaalde competenties gebruikt worden in een functie. Daarnaast is ook de antwoordschaal in beide enquêtes verschillend. In de enquête vijf jaar na afstuderen is een vijfpuntsschaal gehanteerd waarin ook een neutrale antwoordcategorie mogelijk was, terwijl in de enquête een jaar na afstuderen een vierpuntsschaal is gehanteerd waarin geen neutrale antwoordcategorie mogelijk was en men dus gedwongen werd een keuze te maken tussen belangrijk of onbelangrijk. Verder zijn de competenties waarnaar gevraagd is niet precies hetzelfde. Door deze verschillen in vraagstelling is het presenteren van een percentage van afgestudeerden, dat een bepaalde competentie belangrijk vindt dan wel gebruikt, niet zinvol. In plaats van percentages zullen daarom in tabel 3.3 rangordenummers, die het relatieve belang van de competenties ten opzichte van elkaar, gepresenteerd worden. Hierbij krijgt de belangrijkste of vaakst gebruikte competenties rangordenummer 1 , degene die qua belang/gebruik hierop volgt nummer 2 enz. tot aan de minst belangrijke/gebruikte competentie die nummer 9 krijgt. In de bijlage is wel een tabel opgenomen waarin percentages gepresenteerd worden. Alleen die competenties waar in beide jaren op een vergelijkbare manier naar is gevraagd, worden in tabel 3.3 gepresenteerd.

Wanneer we in tabel 3.3 kijken naar de UM als totaal, dan zien we dat er tijdens de loopbaan nauwelijks verschil is te zien in de relevantie van bepaalde competenties voor het werk van UM-afgestudeerden. Competenties die men een jaar na afstuderen belangrijk vindt, zoals communicatieve vaardigheden en zelfstandigheid blijken vijf jaar na afstuderen ook vaak gebruikt te worden. Omgekeerd geldt dat competenties die men een jaar na afstuderen niet belangrijk vindt, zoals internationale oriëntatie en met cijfers omgaan, ook vijf jaar na afstuderen minder vaak gebruikt te worden. Zelfs leidinggeven, waarvan men zou verwachten dat deze belangrijker wordt naarmate men verder komt in de loopbaan, is niet belangrijker geworden. Wanneer we kijken naar de rangordenummers die over de jaren heen met meer dan één punt van elkaar verschillen, dan zien we dat alleen de relevantie van plannen en organiseren tijdens de loopbaan is veranderd. Plannen en organiseren blijkt gaandeweg de loopbaan, waarschijnlijk door een toename van verantwoordelijkheden, belangrijker te worden. Vijf jaar na afstuderen blijkt plannen en organiseren zelfs de op één na belangrijkste competentie te zijn.

In de banen van economen en gezondheidswetenschappers zien we tijdens de loopbaan de meeste veranderingen wat competenties betreft. Zowel voor de banen van economen als voor de banen van gezondheidswetenschappers is nauwkeurigheid gaandeweg de loopbaan veel minder belangrijk geworden. Het zou kunnen zijn dat men gaandeweg de loopbaan andere werkzaamheden heeft gekregen, waarbij nauwkeurigheid minder belangrijk is geworden. Een andere 
mogelijkheid is dat men gaandeweg de loopbaan meer geroutineerd is geraakt bij de uitvoering van dezelfde werkzaamheden. Verder zien we dat bij economen het omgaan met cijfers gaandeweg de loopbaan belangrijker is geworden. Dit komt wellicht door een toename van budgettaire verantwoordelijkheden. Voor gezondheidswetenschappers is computergebruik belangrijker geworden. Dit hoeft echter geen loopbaaneffect te zijn, maar zou ook te maken kunnen hebben met de in de loop van de tijd toegenomen informatisering.

Tabel 3.3

Relevantie competenties tijdens de loopbaan (één en vijf jaar na afstuderen) a.h.v. rangordenummers, cohort ' $94^{*}$

\begin{tabular}{|c|c|c|c|c|c|c|c|c|c|c|}
\hline \multirow[b]{2}{*}{ Jaar na afstuderen: } & \multicolumn{2}{|c|}{ FdEWB } & \multicolumn{2}{|c|}{ FdG } & \multicolumn{2}{|c|}{ FdGW } & \multicolumn{2}{|c|}{ FdR } & \multicolumn{2}{|c|}{ UM Totaal } \\
\hline & $1 \mathrm{jr}$. & $5 \mathrm{jr}$. & $1 \mathrm{jr}$. & $5 \mathrm{jr}$. & 1jr. & $5 \mathrm{jr}$. & 1jr. & $5 \mathrm{jr}$. & 1jr. & $5 \mathrm{jr}$. \\
\hline Vakkennis & 5 & 5 & 1 & 2 & 4 & 5 & 3 & 4 & 3 & 4 \\
\hline $\begin{array}{l}\text { Vakspecifieke } \\
\text { methoden en }\end{array}$ & & & & & & & & & & \\
\hline technieken & 6 & 7 & 4 & 4 & 5 & 6 & 4 & 5 & 5 & 6 \\
\hline $\begin{array}{l}\text { Computergebruik } \\
\text { Met cijfers om }\end{array}$ & 4 & 3 & 7 & 7 & 6 & 4 & 6 & 6 & 6 & 5 \\
\hline $\begin{array}{l}\text { kunnen gaan } \\
\text { Communicatieve }\end{array}$ & 7 & 4 & 8 & 8 & 8 & 7 & 8 & 8 & 8 & 7 \\
\hline vaardigheden & 1 & 1 & 2 & 1 & 2 & 1 & 1 & 1 & 1 & 1 \\
\hline $\begin{array}{l}\text { Plannen en } \\
\text { organiseren }\end{array}$ & 3 & 2 & 6 & 5 & 3 & 2 & 5 & 3 & 4 & 2 \\
\hline Leidinggeven & 8 & 8 & 5 & 6 & 7 & 8 & 7 & 7 & 7 & 8 \\
\hline Nauwkeurigheid & 2 & 6 & 3 & 3 & 1 & 3 & 2 & 2 & 2 & 3 \\
\hline
\end{tabular}

* Een jaar na afstuderen (meetjaar 1995) betreft de rangorde het deel dat aangeeft de competentie (zeer) belangrijk te vinden (3,4 op vierpuntsschaal lopend van 1 'onbelangrijk' tot en met 4 'zeer belangrijk'). Vijf jaar na afstuderen (meetjaar 2000) betreft de rangorde het deel dat aangeeft de competentie (redelijk) intensief te gebruiken (4,5 op vijfpuntsschaal lopend van 1 'niet' tot en met 5 'in hoge mate'). Zie bijlage voor de precieze percentages.

\subsection{Benutting en ontwikkeling van competenties vijf en tien jaar na afstuderen}

In deze paragraaf zullen we kijken naar de mate waarin UM-afgestudeerden hun competenties in het werk kunnen benutten dan wel ontwikkelen. Tevens zal gekeken worden naar de tevredenheid van UM-afgestudeerden met hun baan.

In figuur 3.1 is te zien dat iets meer dan driekwart van de UM-afgestudeerden zijn kennis en vaardigheden goed kan benutten en ontwikkelen in het werk. Driekwart van de UM-afgestudeerden denkt zijn kennis en vaardigheden ook in de toekomst te kunnen blijven benutten in het werk. Het werk van UM-afgestudeerden blijkt dus genoeg uitdaging te bieden.

Medici zijn het meest positief over de benutting en de ontwikkeling van kennis en vaardigheden in hun werk. Gezondheidswetenschappers zijn hierover het minst positief. Zij zien het minst vaak mogelijkheden om hun kennis en vaardigheden ook in de toekomst te kunnen blijven benutten in hun werk. 
Wanneer we kijken naar de tevredenheid met het werk (zie figuur 3.2), dan zien we dat slechts ongeveer een vijfde deel van de UM-afgestudeerden niet tevreden is met hun werk. Gezondheidswetenschappers zijn wat minder vaak tevreden dan andere UM-afgestudeerden. Wellicht komt dit doordat zij minder mogelijkheden hebben om zich verder te ontwikkelen in hun werk.

Figuur 3.1

Benutting en ontwikkeling van competenties vijf en tien jaar na afstuderen, resp. cohort ' 89 en cohort '94

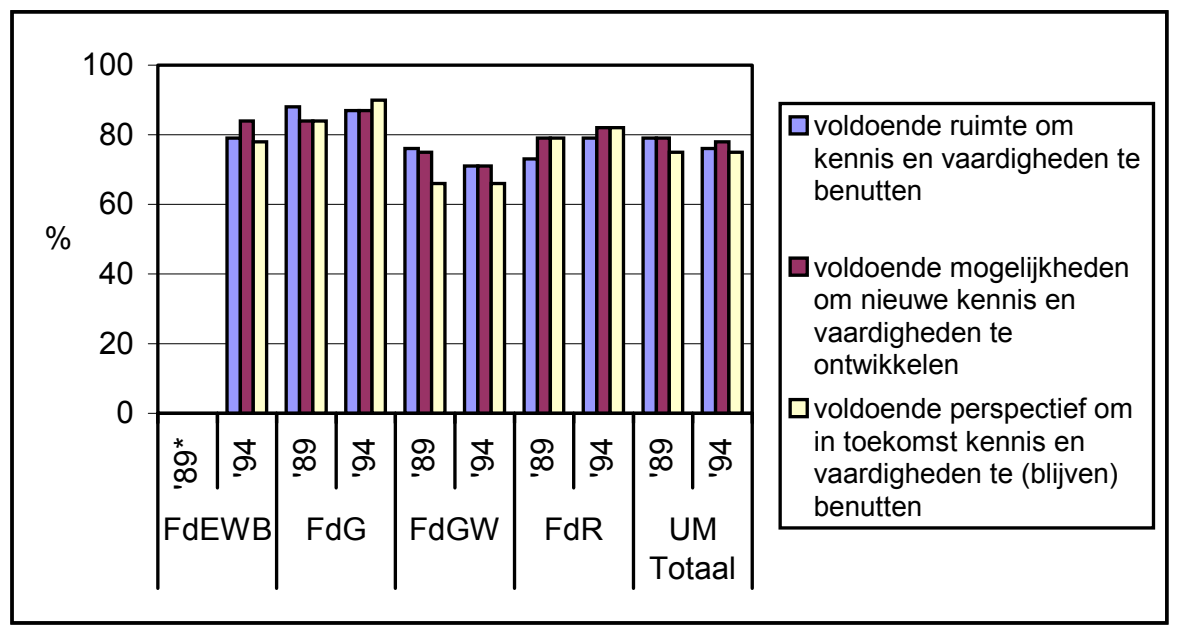

* de groep is te klein om over te rapporteren

Figuur 3.2

Tevredenheid met werk vijf en tien jaar na afstuderen, resp. cohort ' 89 en cohort ' 94

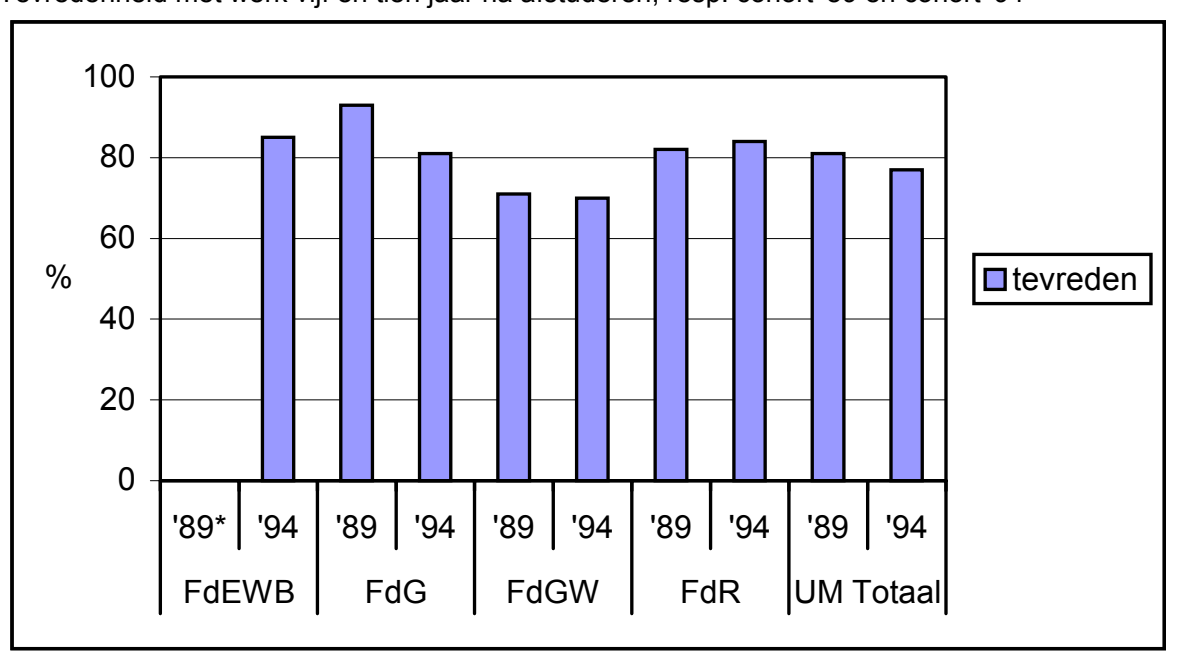

* de groep is te klein om over te rapporteren 


\subsection{Conclusie}

Zeer goed zelfstandig kunnen werken en beschikken over zeer goede communicatieve vaardigheden is vaak belangrijk in de banen van UM-afgestudeerden. Daarnaast is het belangrijk dat UM-afgestudeerden initiatief kunnen nemen, kunnen plannen en organiseren, kunnen omgaan met- en inspelen op veranderingen, nauwkeurig zijn, kunnen werken in teamverband en over voldoende vakkennis beschikken. Internationale oriëntatie, met cijfers om kunnen gaan en leidinggeven is minder belangrijk. Wat de relevantie van competenties betreft verandert er gaandeweg de loopbaan niet veel. Alleen plannen en organiseren blijkt gaandeweg de loopbaan belangrijker te worden. De meerderheid van de UM-afgestudeerden heeft een baan waarin hij/zij zijn competenties goed kan benutten en ontwikkelen.

De banen van economen worden gekenmerkt door het omgaan met cijfers, computergebruik en internationale oriëntatie. In de banen van medici en juristen is een zeer goede beheersing van vakspecifieke kennis en vaardigheden en nauwkeurigheid vaak vereist. Juristen blijken relatief vaak 'solo-functies' te hebben. Voor de banen van gezondheidswetenschappers is een zeer goede beheersing van vakspecifieke kennis en vaardigheden minder belangrijk, maar zijn generieke vaardigheden zoals werken in teamverband en plannen en organiseren belangrijker. 


\section{Typering van banen}

Hoe kunnen de banen van afgestudeerden van de Universiteit Maastricht getypeerd worden?

In dit hoofdstuk zal nader ingegaan worden op het type banen dat UM-afgestudeerden hebben. Er zal een indeling gemaakt worden in drie type banen en per type baan zal bekeken worden welke competenties belangrijk zijn.

\subsection{Type banen}

Om meer zicht te krijgen op het type banen dat UM-afgestudeerden vijf en tien jaar na afstuderen hebben, is hen een negentiental aspecten voorgelegd waarbij zij aan moesten geven in hoeverre deze van toepassing zijn op hun huidige baan. De schaal waarop gescoord kon worden, liep van 1 'helemaal niet' tot en met 5 'in sterke mate'. De scores op een aantal van deze aspecten hielden sterk met elkaar verband. Dat wil zeggen, dat een hoge score op bijvoorbeeld macht en invloed samengaat met een hoge score op leidinggeven/coördinatie. Aan de hand van een factoranalyse konden de verschillende aspecten geclusterd worden in drie factoren (zie tabel 4.1). De eerste heeft betrekking op de statusgerichtheid van een baan. Macht en invloed, hoog salaris, leidinggeven, sociale status, afwisseling, carrièreperspectieven, en baanzekerheid laden hoog op deze factor. De tweede factor heeft betrekking op de intellectuele ontwikkeling binnen een baan. Hieronder vallen de aspecten wetenschappelijke verdieping, toepassing van kennis en vaardigheden, mogelijkheden om bij te leren, uitdaging en inbreng van eigen ideeën. De derde factor betreft de sociale gerichtheid van een baan. Aspecten die hier hoog op laden zijn: genoeg tijd voor de vrijetijdsbesteding, maatschappelijk nut, goede sfeer, duidelijk gestructureerde werktaken, werken in teamverband. Het onderscheid tussen de eerste twee factoren is echter niet heel erg scherp aangezien er een aantal aspecten zijn, namelijk carrièreperspectieven, uitdaging, inbreng van eigen ideeën en afwisseling, die zowel hoog laden op de eerste als op de tweede factor. Door deze drie factoren wordt in totaal iets minder dan de helft $(43 \%)$ van de spreiding in de antwoorden (variantie) verklaard.

Uit de factoranalyse komen dus drie factoren naar voren die in meer of mindere mate betrekking kunnen hebben op een baan, namelijk statusgerichtheid, intellectuele ontwikkeling en sociale gerichtheid. Aan de hand van de scores op de drie factoren kan bekeken worden of de betreffende factor in meer of mindere mate van toepassing is op een bepaalde baan. Deze factorscores zijn globaal in te delen in drie categorieën, namelijk <-0.5= laag, $-0.5-0.5=$ gemiddeld en $>0.5=$ hoog. In figuur 4.1 is het percentage weergegeven dat aangeeft dat de betreffende factor in sterke mate van toepassing is op zijn/haar baan (factorscore $>0.5$ ). 
Tabel 4.1

Clustering baanaspecten vijf en tien jaar na afstuderen, cohort ' 94 en cohort ' 89 samen*

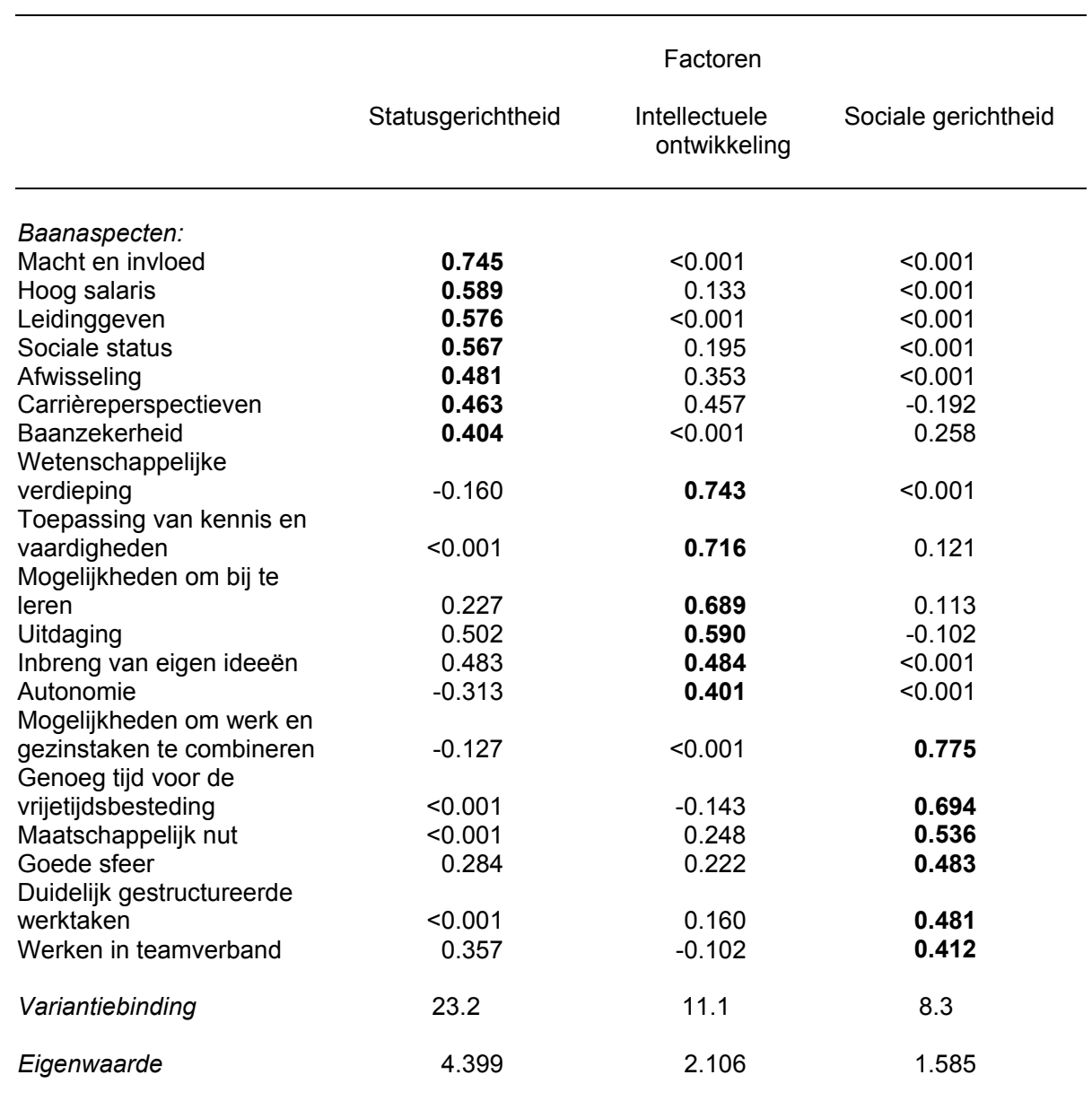

* Clustering vindt plaats aan de hand van factoranalyse. Gepresenteerd worden factorladingen, variantiebinding en eigenwaarde.

Afgestudeerden van de verschillende studierichtingen blijken verschillende type banen te hebben (zie figuur 4.1). Economen hebben vaak banen met veel statusgerichtheid. Medici hebben vaker banen met veel intellectuele ontwikkeling en met veel sociale gerichtheid. Juristen uit cohort ' 94 blijken redelijk vaak banen te hebben met veel intellectuele ontwikkeling. De banen van juristen uit cohort '89 en gezondheidswetenschappers blijken niet gekarakteriseerd te kunnen worden door veel statusgerichtheid en ook niet door veel intellectuele ontwikkeling of sociale gerichtheid. Zij hebben wellicht heterogene banen. Het verschil in het type baan van juristen uit cohort '89 en juristen uit cohort '94 zou verklaard kunnen worden doordat juristen uit cohort ' 89 minder vaak in hun eigen opleidingsrichting werkzaam zijn (zie figuur 2.5) 
Figuur 4.1

Typering van banen vijf en tien jaar na afstuderen, resp. cohort ' 94 en cohort ' 89 *

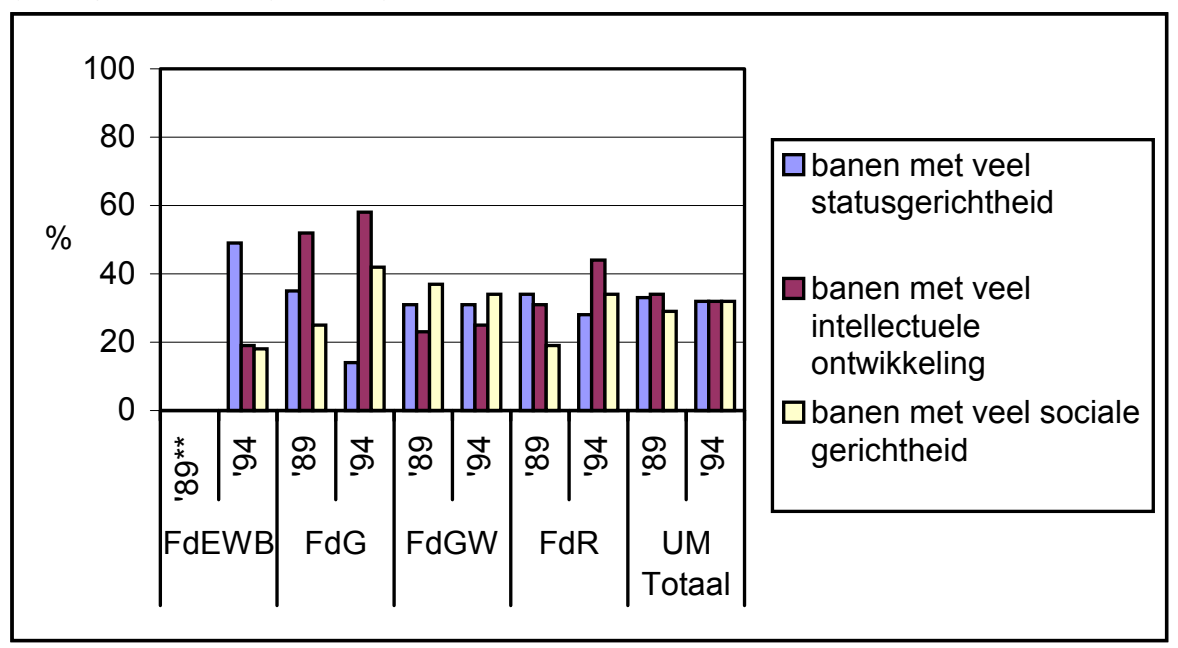

* De indeling is echter niet uitsluitend, aangezien een baan die op twee factoren hoog scoort in twee categorieën terecht komt, terwijl een andere baan die op geen enkele categorie hoog scoort in geen enkele categorie terecht komt.

** de groep is te klein om over te rapporteren

\subsection{Gebruik van competenties in elk type baan}

In deze paragraaf zal worden bekeken of men in deze drie type banen ook verschillende competenties gebruikt. Hierbij zal alleen gerapporteerd worden over de banen van afstudeercohort ' 94 vijf jaar na afstuderen.

In tabel 4.2 is te zien hoe vaak competenties (redelijk) intensief gebruikt worden in een bepaald type baan. De tabel laat zien dat men in banen met veel statusgerichtheid relatief vaak moet plannen en organiseren, leidinggeven, initiatief nemen en moet omgaan met- en inspelen op veranderingen. Naast deze competenties worden banen met veel statusgerichtheid ook gekenmerkt door het gebruik van computers en het omgaan met cijfers.

Voor banen met veel intellectuele ontwikkeling is het gebruik van vakspecifieke kennis en vaardigheden en nauwkeurigheid belangrijk. Werken in teamverband is in deze banen minder belangrijk. In deze banen zal er vaker alleen gewerkt worden.

Voor banen met veel sociale gerichtheid lijken er geen specifieke competenties vereist te worden. $\mathrm{Er}$ is namelijk geen enkele competentie aan te wijzen die men in deze banen vaker gebruikt dan in andere type banen. Wel blijken banen met sociale gerichtheid gekarakteriseerd te kunnen worden door het minder frequente gebruik van creativiteit. 
Tabel 4.2

Gebruik van competenties (\% (redelijk) vaak), cohort '94

\begin{tabular}{|c|c|c|c|}
\hline & $\begin{array}{c}\text { Status- } \\
\text { gerichtheid } \\
(n=120) \\
\%\end{array}$ & $\begin{array}{c}\text { Intellectuele } \\
\text { ontwikkeling } \\
(\mathrm{n}=118) \\
\%\end{array}$ & $\begin{array}{c}\text { Sociale } \\
\text { gerichtheid } \\
(n=115) \\
\%\end{array}$ \\
\hline \multicolumn{4}{|l|}{ Banen met veel: } \\
\hline Vakkennis & 78 & 92 & 76 \\
\hline Vakspecifieke methoden en technieken & 61 & 86 & 68 \\
\hline Computergebruik & 80 & 68 & 70 \\
\hline Met cijfers om kunnen gaan & 68 & 48 & 43 \\
\hline Communicatieve vaardigheden & 100 & 95 & 97 \\
\hline Werken in teamverband & 88 & 72 & 84 \\
\hline Plannen en organiseren & 93 & 85 & 84 \\
\hline Leidinggeven & 62 & 35 & 33 \\
\hline Zelfstandigheid & 99 & 99 & 94 \\
\hline Creativiteit & 73 & 79 & 68 \\
\hline Initiatief & 95 & 91 & 84 \\
\hline \multicolumn{4}{|l|}{ Omgaan met en inspelen op } \\
\hline veranderingen & 89 & 82 & 83 \\
\hline Nauwkeurigheid & 76 & 92 & 85 \\
\hline Internationale oriëntatie & 26 & 24 & 20 \\
\hline
\end{tabular}

\subsection{Vereist niveau van competenties in elk type baan}

In tabel 4.3 is te zien hoe vaak een uitmuntende beheersing van competenties vereist is in een bepaald type baan.

In banen met veel statusgerichtheid is een uitmuntende beheersing van competenties vaker vereist dan in de andere type banen. Zo dienen organisatorische competenties, namelijk plannen en organiseren, leidinggeven en omgaan met en inspelen op veranderingen in deze banen relatief vaak uitmuntend beheerst te worden. Daarnaast is een uitmuntende beheersing van interpersoonlijke competenties, zoals communicatieve vaardigheden en werken in teamverband, vaker vereist en dient men in deze banen zeer goed met cijfers kunnen omgaan.

Banen met veel intellectuele ontwikkeling kenmerken zich door het hogere niveau waarop nauwkeurigheid en vakspecifieke methoden en technieken vereist worden.

In banen met veel sociale gerichtheid is een uitmuntende beheersing van competenties het minst vaak vereist. In de vorige paragraaf zagen we al dat er voor deze banen ook geen specifieke competenties vereist worden. In deze banen worden waarschijnlijk minder hoge eisen gesteld aan de capaciteiten van werknemers. 
Tabel 4.3

Vereist niveau van competenties (\% uitmuntend), cohort '94

\begin{tabular}{|c|c|c|c|}
\hline & $\begin{array}{c}\text { Status- } \\
\text { gerichtheid } \\
(\mathrm{n}=120) \\
\%\end{array}$ & $\begin{array}{c}\text { Intellectuele } \\
\text { ontwikkeling } \\
(n=118) \\
\%\end{array}$ & $\begin{array}{c}\text { Sociale } \\
\text { gerichtheid } \\
(n=115) \\
\%\end{array}$ \\
\hline \multicolumn{4}{|l|}{ Banen met veel: } \\
\hline Vakkennis & 25 & 25 & 16 \\
\hline Vakspecifieke methoden en technieken & 24 & 30 & 19 \\
\hline Computergebruik & 12 & 9 & 3 \\
\hline Met cijfers om kunnen gaan & 21 & 15 & 12 \\
\hline Communicatieve vaardigheden & 58 & 47 & 47 \\
\hline Werken in teamverband & 33 & 24 & 28 \\
\hline Plannen en organiseren & 40 & 29 & 28 \\
\hline Leidinggeven & 23 & 13 & 13 \\
\hline Zelfstandigheid & 52 & 50 & 39 \\
\hline Creativiteit & 19 & 22 & 13 \\
\hline Initiatief & 33 & 30 & 21 \\
\hline $\begin{array}{l}\text { Omgaan met en inspelen op } \\
\text { veranderingen }\end{array}$ & 39 & 24 & 23 \\
\hline Nauwkeurigheid & 28 & 35 & 25 \\
\hline Internationale oriëntatie & 16 & 13 & 10 \\
\hline
\end{tabular}

\subsection{Benutting en ontwikkeling van competenties in elk type baan}

In hoeverre de drie type banen verschillen wat betreft de mogelijkheden om competenties te benutten en te ontwikkelen en wat betreft de tevredenheid met de baan zal in deze paragraaf bekeken worden.

In figuur 4.2 is te zien dat men in banen met veel statusgerichtheid iets minder mogelijkheden heeft om competenties (kennis en vaardigheden) te benutten en te ontwikkelen dan in banen met veel intellectuele ontwikkeling. Desondanks is men toch even vaak tevreden met de baan als afgestudeerden met een baan met veel intellectuele ontwikkeling.

In banen met veel intellectuele ontwikkeling kan men competenties het beste benutten en ziet men de meeste ontwikkelingsmogelijkheden en perspectieven om competenties ook in de toekomst te kunnen (blijven) benutten. Dit komt waarschijnlijk doordat het gebruik van vakspecifieke competenties in deze banen erg belangrijk is (zie tabel 4.2) en men zich hierin moet blijven ontwikkelen. Het goed kunnen benutten en ontwikkelen van competenties zorgt waarschijnlijk voor de grote tevredenheid in dit type banen.

In banen met veel sociale gerichtheid is het minst vaak ruimte om kennis en vaardigheden te benutten. De competenties van UM-afgestudeerden worden in dit soort banen waarschijnlijk onvoldoende benut, doordat er relatief weinig van hen gevraagd wordt (zie paragraaf 4.2 en 4.3). Hierdoor ziet men waarschijnlijk ook minder ontwikkelingsmogelijkheden en perspectief om kennis en vaardigheden in de 
toekomst te (blijven) benutten. In banen met veel sociale gerichtheid is men dan ook minder vaak tevreden met hun baan.

Figuur 4.2

Benutting en ontwikkeling van competenties en tevredenheid met het werk, cohort ' 94

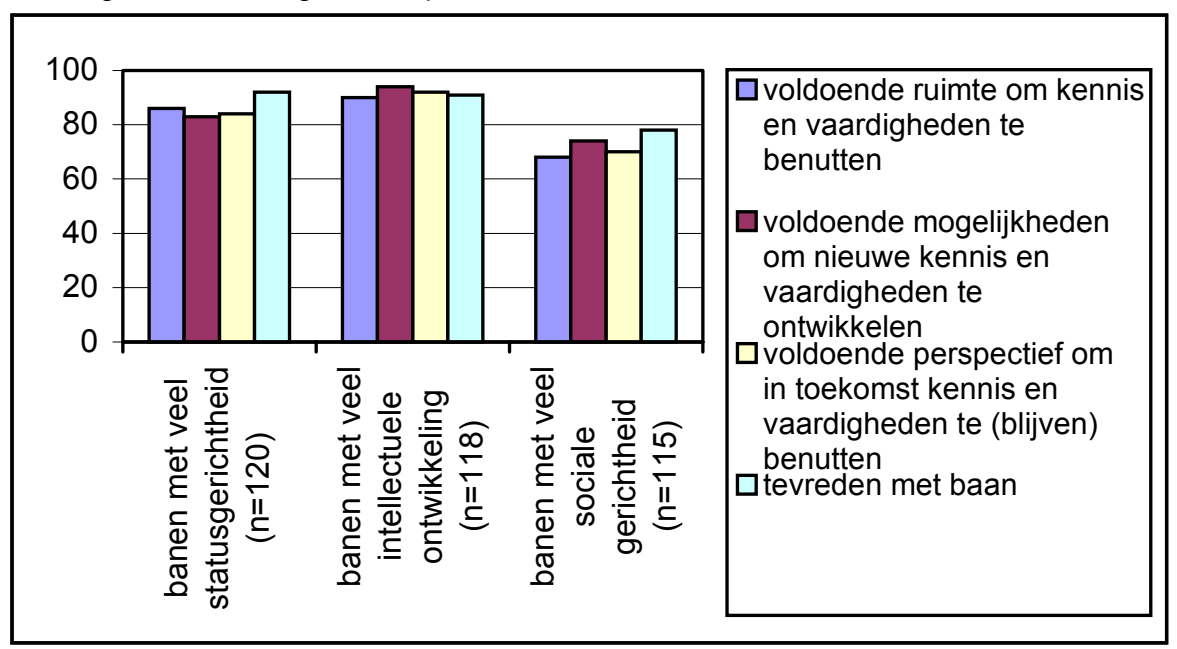

\subsection{Conclusie}

Er zijn drie type banen te onderscheiden. Het eerste type betreft banen met veel statusgerichtheid die gekenmerkt worden door macht en invloed, hoog salaris, sociale status en carrièreperspectieven. Vooral economen hebben dit soort banen. In deze banen wordt vaak een zeer goede beheersing van organisatorische competenties vereist. Daarnaast dient men in dit type banen zeer goed om te kunnen gaan met mensen en is zeer goed om kunnen gaan met cijfers belangrijk.

Het tweede type betreft banen met veel intellectuele ontwikkeling die gekenmerkt worden door het goed kunnen toepassen van kennis en vaardigheden, mogelijkheden om bij te leren en inbreng van eigen ideeën. Vooral medici en juristen hebben dit soort banen. In deze banen is vaak een zeer goede beheersing van vakspecifieke kennis en vaardigheden en nauwkeurigheid vereist en heeft men veel mogelijkheden om kennis en vaardigheden te benutten en te ontwikkelen.

Het derde type betreft banen met veel sociale gerichtheid die gekenmerkt worden door het hebben van genoeg tijd voor de vrijetijdsbesteding, maatschappelijk nut, goede sfeer en duidelijk gestructureerde werktaken. In deze banen is een zeer goede beheersing van specifieke competenties minder belangrijk en heeft men minder ruimte voor de benutting en ontwikkeling van kennis en vaardigheden. 


\section{Rol van de opleiding bij de ontwikkeling van competenties}

Welke rol speelt de opleiding bij de ontwikkeling van competenties?

In dit hoofdstuk zal bekeken worden welke rol de opleiding speelt bij de ontwikkeling van competenties. Waar hebben UM-afgestudeerden hun competenties geleerd? Welke competenties vinden zij te weinig aan bod gekomen in de opleiding? Hebben zij in de opleiding voldoende kennis en vaardigheden opgedaan voor hun werk?

\subsection{Leerbronnen van competenties}

Aan respondenten is gevraagd waar zij bepaalde competenties voornamelijk geleerd hebben. Hierbij waren drie antwoordcategorieën mogelijk, namelijk tijdens de WOopleiding, op het werk of elders. In tabel 5.1 is te zien hoe vaak een bepaalde competentie voornamelijk tijdens de WO-opleiding, respectievelijk het werk of door andere ervaringen geleerd wordt. Aangezien UM-afgestudeerden uit cohort '94 en cohort '89 beiden al een tijd (respectievelijk vijf en tien jaar) werkzaam zijn, verwachten we weinig verschil in de leerbronnen die zij noemen van hun competenties. Een groter verschil valt er te verwachten tussen de leerbronnen die UM-afgestudeerden een en vijf jaar na afstuderen noemen. Een jaar na afstuderen werkt men namelijk nog niet zo lang en zal de rol van de opleiding bij de ontwikkeling van competenties waarschijnlijk groter zijn dan vijf jaar na afstuderen. In deze paragraaf zal dan ook een vergelijking gemaakt worden tussen de periode een en vijf jaar na afstuderen. Aangezien er voor cohort '94 geen gegevens zijn over de leerbronnen die zij een jaar na afstuderen noemen, zal een jaar na afstuderen gerapporteerd worden over cohort ' 99.

Leerbronnen van competenties vijf jaar na afstuderen

Uit tabel 5.1 blijkt dat het werk vijf jaar na afstuderen voor alle competenties de belangrijkste leerbron is. Blijkbaar heeft men na de opleiding tijdens het werk nog heel veel geleerd. Er is wel een onderscheid te maken tussen competenties die bijna alleen maar voornamelijk tijdens het werk zijn geleerd, competenties die zowel tijdens het werk als tijdens de opleiding zijn geleerd, competenties die vooral tijdens het werk en elders zijn geleerd en competenties die zowel tijdens het werk, als tijdens de opleiding en elders zijn geleerd.

Computergebruik, plannen en organiseren, leidinggeven, omgaan met en inspelen op veranderingen zijn competenties die door de meerderheid van de UMafgestudeerden vijf jaar na afstuderen tijdens het werk zijn geleerd. Vooral de laatste twee competenties zal men tijdens de opleiding niet vaak gebruikt hebben. 
Vakkennis, vakspecifieke methoden en technieken en werken in teamverband zijn competenties die men zowel op het werk als tijdens de opleiding leert. Blijkbaar is het werk dus ook voor vakspecifieke kennis en vaardigheden een belangrijke leerbron. Het werken in teamverband zal tijdens de opleiding vooral geleerd worden door het werken in onderwijsgroepen.

Initiatief en creativiteit worden niet zo vaak tijdens de opleiding geleerd, maar vaker tijdens het werk of elders.

Communicatieve vaardigheden, zelfstandigheid, nauwkeurigheid, internationale oriëntatie en met cijfers om kunnen gaan, zijn competenties die zowel op het werk, als tijdens de opleiding en elders worden geleerd. De eerste drie competenties worden in verschillende situaties gebruikt en het is dan ook niet zo verwonderlijk is dat hiervoor meerdere leerbronnen zijn. Internationale oriëntatie zal men ook vaak tijdens de opleiding leren, aangezien ongeveer een derde deel van de UMafgestudeerden tijdens de opleiding buitenlandervaring opdoet (zie tabel 2.2). Het om kunnen gaan met cijfers blijkt opvallend genoeg niet alleen tijdens de opleiding of op het werk maar ook vaak elders geleerd te worden.

\section{Verschillen in leerbronnen een en vijf jaar na afstuderen}

Een jaar na afstuderen blijkt men ook al veel geleerd te hebben tijdens het werk. Echter ook de opleiding speelt dan nog een grote rol bij de ontwikkeling van competenties. Voor vakkennis, met cijfers om kunnen gaan, werken in teamverband, zelfstandigheid en internationale oriëntatie is de opleiding een jaar na afstuderen zelfs de belangrijkste leerbron.

\section{Verschillen in leerbronnen tussen studierichtingen}

Wanneer we kijken naar verschillen tussen de studierichtingen dan zien we dat economen met cijfers om kunnen gaan en internationale oriëntatie vaker dan andere UM-afgestudeerden tijdens de opleiding hebben geleerd. Waarschijnlijk zal de opleiding economie hieraan relatief veel aandacht hebben besteed, omdat dit voor economen belangrijke competenties zijn (zie tabel 3.1). Medici blijken de voor hun belangrijke competenties, namelijk vakkennis en communicatieve vaardigheden (zie tabel 3.1), vaker tijdens de opleiding te hebben geleerd. Wat opvalt bij gezondheidswetenschappers is dat zij minder vaak vakspecifieke methoden en technieken tijdens het werk leren. Dit zal waarschijnlijk komen doordat het op hoog niveau beheersen van vakspecifieke methoden en technieken voor de banen van gezondheidswetenschappers minder belangrijk is (zie tabel 3.2). Juristen hebben het omgaan met cijfers relatief vaak tijdens het werk geleerd. 
Tabel 5.1

Leerbronnen van competenties een jaar (cohort '99) en vijf jaar na afstuderen (cohort '94)*

\begin{tabular}{|c|c|c|c|c|c|c|c|c|c|c|}
\hline \multirow[b]{2}{*}{$\begin{array}{l}\text { Jaar na afstuderen: } \\
\text { Cohort: }\end{array}$} & \multicolumn{2}{|c|}{ FdEWB } & \multicolumn{2}{|c|}{ FdG } & \multicolumn{2}{|c|}{ FdGW } & \multicolumn{2}{|c|}{ FdR } & \multicolumn{2}{|c|}{ UM Totaal } \\
\hline & $\begin{array}{l}\text { 1jr. } \\
\text { '99 } \\
\%\end{array}$ & $\begin{array}{r}5 \mathrm{jr} . \\
\text { '94 } \\
\%\end{array}$ & $\begin{array}{r}1 \mathrm{jr} . \\
\text { '99 } \\
\%\end{array}$ & $\begin{array}{r}5 \mathrm{jr} . \\
\text { '94 } \\
\%\end{array}$ & $\begin{array}{r}1 \mathrm{jr} . \\
\text { '99 } \\
\%\end{array}$ & $\begin{array}{r}5 \mathrm{jr} . \\
\text { '94 } \\
\%\end{array}$ & $\begin{array}{r}1 \text { jr. } \\
\text { '99 } \\
\%\end{array}$ & $\begin{array}{r}5 \mathrm{jr} . \\
\text { '94 } \\
\%\end{array}$ & $\begin{array}{r}1 \mathrm{jr} . \\
\text { '99 } \\
\%\end{array}$ & $\begin{array}{r}5 \mathrm{jr} . \\
\text { '94 } \\
\%\end{array}$ \\
\hline
\end{tabular}

\begin{tabular}{|c|c|c|c|c|c|c|c|c|c|c|}
\hline \multicolumn{11}{|l|}{ Vakkennis } \\
\hline WO-opleiding & 47 & 40 & 64 & 53 & 59 & 40 & 61 & 39 & 57 & 41 \\
\hline Werk & 51 & 56 & 34 & 43 & 39 & 53 & 35 & 53 & 41 & 52 \\
\hline Overig & 2 & 5 & 2 & 4 & 2 & 7 & 5 & 9 & 3 & 6 \\
\hline \multicolumn{11}{|l|}{$\begin{array}{l}\text { methoden en } \\
\text { technieken }\end{array}$} \\
\hline WO-opleiding & 34 & 30 & 39 & 26 & 62 & 50 & 34 & 20 & 45 & 37 \\
\hline Werk & 64 & 62 & 59 & 68 & 38 & 42 & 63 & 68 & 53 & 55 \\
\hline Overig & 2 & 8 & 2 & 6 & 1 & 8 & 3 & 13 & 2 & 8 \\
\hline \multicolumn{11}{|c|}{ Computergebruik } \\
\hline WO-opleiding & 37 & 9 & 13 & 6 & 34 & 13 & 16 & 9 & 28 & 10 \\
\hline Werk & 40 & 76 & 39 & 59 & 39 & 56 & 58 & 66 & 42 & 63 \\
\hline Overig & 24 & 16 & 48 & 35 & 27 & 32 & 26 & 26 & 30 & 27 \\
\hline \multicolumn{11}{|l|}{ Met cijfers om } \\
\hline \multicolumn{11}{|l|}{ kunnen gaan } \\
\hline WO-opleiding & 76 & 56 & 47 & 23 & 55 & 33 & 28 & 17 & 57 & 35 \\
\hline Werk & 13 & 32 & 23 & 28 & 27 & 42 & 43 & 47 & 24 & 39 \\
\hline Overig & 10 & 12 & 31 & 49 & 18 & 25 & 28 & 36 & 19 & 26 \\
\hline \multicolumn{11}{|c|}{$\begin{array}{l}\text { Communicatieve } \\
\text { vaardigheden }\end{array}$} \\
\hline WO-opleiding & 40 & 28 & 56 & 49 & 31 & 30 & 26 & 10 & 38 & 28 \\
\hline Werk & 31 & 55 & 24 & 29 & 41 & 42 & 40 & 51 & 35 & 45 \\
\hline Overig & 29 & 17 & 20 & 22 & 27 & 28 & 34 & 39 & 28 & 26 \\
\hline \multicolumn{11}{|l|}{$\begin{array}{l}\text { Werken in } \\
\text { teamverband }\end{array}$} \\
\hline WO-opleiding & 69 & 41 & 23 & 27 & 39 & 36 & 38 & 24 & 45 & 34 \\
\hline Werk & 12 & 45 & 61 & 48 & 45 & 48 & 33 & 62 & 36 & 49 \\
\hline Overig & 19 & 14 & 17 & 25 & 16 & 16 & 30 & 15 & 19 & 17 \\
\hline \multicolumn{11}{|l|}{$\begin{array}{l}\text { Plannen en } \\
\text { organiseren }\end{array}$} \\
\hline WO-opleiding & 35 & 26 & 13 & 12 & 24 & 14 & 13 & 12 & 24 & 17 \\
\hline Werk & 37 & 59 & 60 & 57 & 55 & 67 & 49 & 62 & 49 & 63 \\
\hline Overig & 28 & 15 & 27 & 31 & 21 & 19 & 38 & 26 & 27 & 21 \\
\hline \multicolumn{11}{|l|}{ Leidinggeven } \\
\hline WO-opleiding & 13 & 5 & 6 & 2 & 23 & 9 & 7 & 2 & 15 & 6 \\
\hline Werk & 45 & 74 & 57 & 72 & 54 & 73 & 50 & 69 & 52 & 72 \\
\hline Overig & 42 & 21 & 37 & 26 & 23 & 19 & 43 & 29 & 34 & 22 \\
\hline \multicolumn{11}{|l|}{ Zelfstandigheid } \\
\hline WO-opleiding & 47 & 44 & 23 & 28 & 35 & 34 & 40 & 28 & 37 & 35 \\
\hline Werk & 21 & 37 & 46 & 44 & 35 & 38 & 32 & 32 & 32 & 38 \\
\hline Overig & 32 & 19 & 31 & 28 & 30 & 28 & 28 & 40 & 31 & 28 \\
\hline \multicolumn{11}{|l|}{ Creativiteit } \\
\hline WO-opleiding & 20 & 21 & 7 & 15 & 13 & 11 & 20 & 14 & 15 & 14 \\
\hline Werk & 27 & 37 & 33 & 33 & 44 & 42 & 37 & 35 & 36 & 39 \\
\hline Overig & 54 & 43 & 60 & 52 & 44 & 47 & 43 & 51 & 50 & 47 \\
\hline \multicolumn{11}{|l|}{ Initiatief } \\
\hline WO-opleiding & 21 & 25 & 12 & 15 & 15 & 17 & 19 & 20 & 17 & 19 \\
\hline Werk & 35 & 43 & 44 & 40 & 50 & 47 & 38 & 45 & 42 & 45 \\
\hline Overig & 44 & 32 & 45 & 46 & 35 & 37 & 43 & 36 & 41 & 37 \\
\hline
\end{tabular}


Tabel 5.1 (vervolg)

Leerbronnen van competenties een jaar (cohort '99) en vijf jaar na afstuderen (cohort '94)*

\begin{tabular}{|c|c|c|c|c|c|c|c|c|c|c|}
\hline \multirow[b]{2}{*}{$\begin{array}{l}\text { Jaar na afstuderen: } \\
\text { Cohort: }\end{array}$} & \multicolumn{2}{|c|}{ FdEWB } & \multicolumn{2}{|c|}{$\mathrm{FdG}$} & \multicolumn{2}{|c|}{ FdGW } & \multicolumn{2}{|c|}{$\mathrm{FdR}$} & \multicolumn{2}{|c|}{ UM Totaal } \\
\hline & $\begin{array}{r}1 \mathrm{jr} . \\
\text { '99 } \\
\%\end{array}$ & $\begin{array}{r}5 \mathrm{jr} . \\
\text { '94 } \\
\%\end{array}$ & $\begin{array}{r}1 \mathrm{jr} . \\
\text { '99 } \\
\%\end{array}$ & $\begin{array}{r}5 \mathrm{jr} . \\
\text { '94 } \\
\%\end{array}$ & $\begin{array}{r}1 \mathrm{jr} . \\
\text { '99 } \\
\%\end{array}$ & $\begin{array}{r}5 \mathrm{jr} . \\
\text { '94 } \\
\%\end{array}$ & $\begin{array}{r}1 \mathrm{jr} . \\
\text { '99 } \\
\%\end{array}$ & $\begin{array}{r}5 \mathrm{jr} . \\
\text { '94 } \\
\%\end{array}$ & $\begin{array}{r}1 \mathrm{jr} . \\
\text { '99 } \\
\%\end{array}$ & $\begin{array}{r}5 \mathrm{jr} . \\
\text { '94 } \\
\%\end{array}$ \\
\hline $\begin{array}{l}\text { Omgaan met en } \\
\text { inspelen op } \\
\text { veranderingen }\end{array}$ & & & & & & & & & & \\
\hline $\begin{array}{l}\text { WO-opleiding } \\
\text { Werk } \\
\text { Overig }\end{array}$ & $\begin{array}{l}14 \\
42 \\
44\end{array}$ & $\begin{array}{l}14 \\
61 \\
26\end{array}$ & $\begin{array}{l}14 \\
43 \\
43\end{array}$ & $\begin{array}{r}4 \\
63 \\
33\end{array}$ & $\begin{array}{l}17 \\
52 \\
31\end{array}$ & $\begin{array}{l}12 \\
68 \\
20\end{array}$ & $\begin{array}{l}13 \\
54 \\
33\end{array}$ & $\begin{array}{r}8 \\
53 \\
40\end{array}$ & $\begin{array}{l}15 \\
48 \\
38\end{array}$ & $\begin{array}{l}11 \\
63 \\
26\end{array}$ \\
\hline $\begin{array}{l}\text { Nauwkeurigheid } \\
\text { WO-opleiding }\end{array}$ & 35 & 29 & 26 & 16 & 31 & 22 & 29 & 27 & 31 & 24 \\
\hline $\begin{array}{l}\text { Werk } \\
\text { Overig } \\
\text { Internationale } \\
\text { oriëntatie }\end{array}$ & $\begin{array}{l}34 \\
32\end{array}$ & $\begin{array}{l}38 \\
33\end{array}$ & $\begin{array}{l}37 \\
37\end{array}$ & $\begin{array}{l}34 \\
50\end{array}$ & $\begin{array}{l}32 \\
37\end{array}$ & $\begin{array}{l}37 \\
40\end{array}$ & $\begin{array}{l}35 \\
35\end{array}$ & $\begin{array}{l}42 \\
31\end{array}$ & $\begin{array}{l}34 \\
35\end{array}$ & $\begin{array}{l}38 \\
38\end{array}$ \\
\hline $\begin{array}{l}\text { WO-opleiding } \\
\text { Werk } \\
\text { Overig }\end{array}$ & $\begin{array}{l}50 \\
30 \\
20\end{array}$ & $\begin{array}{l}48 \\
41 \\
12\end{array}$ & $\begin{array}{l}39 \\
20 \\
41\end{array}$ & $\begin{array}{l}22 \\
26 \\
52\end{array}$ & $\begin{array}{l}33 \\
37 \\
30\end{array}$ & $\begin{array}{l}33 \\
43 \\
25\end{array}$ & $\begin{array}{l}58 \\
23 \\
19\end{array}$ & $\begin{array}{l}35 \\
35 \\
30\end{array}$ & $\begin{array}{l}44 \\
29 \\
26\end{array}$ & $\begin{array}{l}36 \\
39 \\
25\end{array}$ \\
\hline $\begin{array}{l}\text { Aantal } \\
\text { respondenten }\end{array}$ & 272 & 88 & 176 & 49 & 313 & 173 & 133 & 57 & 894 & 367 \\
\hline
\end{tabular}

\footnotetext{
* Aangezien er een jaar na afstuderen geen gegevens beschikbaar zijn over de leerbronnen van competenties van cohort ' 94 , wordt een jaar na afstuderen gerapporteerd over de leerbronnen van cohort ' 99 .
}

\subsection{Ervaren tekorten in de opleiding}

\section{Tekorten in de opleiding vijf en tien jaar na afstuderen}

UM-afgestudeerden is gevraagd van welke competenties (maximaal drie) zij vinden dat deze tijdens de opleiding te weinig aan bod zijn gekomen. In tabel 5.2 is te zien hoe vaak bepaalde tekorten ervaren worden in hun opleiding. De percenteerbasis is hierbij de groep die minimaal één tekort noemt. Degenen die geen enkel tekort noemen worden buiten beschouwing gelaten, omdat het niet duidelijk is of zij deze vraag hebben overgeslagen of dat zij daadwerkelijk geen tekort hebben ervaren.

Uit tabel 5.2 blijkt dat men vaak vindt dat het leren omgaan met computers te weinig aan bod is gekomen tijdens de opleiding. Afstudeercohort '89 noemt computergebruik vaker als tekort dan cohort '94. Waarschijnlijk komt dit doordat er in de vijf jaren na het afstuderen van cohort '89 tijdens de opleiding meer aandacht is gekomen voor computers. Het is de vraag of men tijdens de opleiding vaker zou moeten leren omgaan met computers. Computergebruik blijkt namelijk vaak op het werk geleerd te worden (zie tabel 5.1) en het is niet zo belangrijk om deze competentie uitmuntend te beheersen (zie tabel 3.2). Naast computergebruik geeft men ook vaak aan dat leidinggeven, plannen en organiseren en omgaan met en inspelen op veranderingen te weinig aan bod is gekomen tijdens de opleiding. Deze competenties blijken vaak pas tijdens het werk geleerd te worden (zie tabel 5.1). 
Wanneer we kijken naar verschillen tussen de studierichtingen, dan valt op dat medici vaker dan andere UM-afgestudeerden vinden dat computergebruik, leidinggeven en plannen en organiseren tijdens de opleiding te weinig aan bod zijn gekomen. Waarschijnlijk is er hiervoor in de medische opleiding minder aandacht geweest dan in de andere opleidingen. Het omgaan met en inspelen op veranderingen vinden medici en juristen minder vaak dan economen en gezondheidswetenschappers te weinig aan bod gekomen tijdens de opleiding. Wellicht is deze competentie voor medici en juristen minder belangrijk dan voor economen en gezondheidswetenschappers.

Tabel 5.2

Tekorten in de opleiding vijf en tien jaar na afstuderen, resp. cohort '94 en cohort '89*

\begin{tabular}{|c|c|c|c|c|c|c|c|c|c|c|}
\hline \multirow[b]{2}{*}{ Cohort: } & \multicolumn{2}{|c|}{ FdEWB } & \multicolumn{2}{|c|}{ FdG } & \multicolumn{2}{|c|}{ FdGW } & \multicolumn{2}{|c|}{$\mathrm{FdR}$} & \multicolumn{2}{|c|}{ UM Totaal } \\
\hline & $\begin{array}{r}\text { '89 } \\
\%\end{array}$ & $\begin{array}{r}' 94 \\
\%\end{array}$ & $\begin{array}{r}89 \\
\%\end{array}$ & $\begin{array}{r}' 94 \\
\%\end{array}$ & $\begin{array}{r}89 \\
\%\end{array}$ & $\begin{array}{r}' 94 \\
\%\end{array}$ & $\begin{array}{r}89 \\
\%\end{array}$ & $\begin{array}{r}' 94 \\
\%\end{array}$ & $\begin{array}{r}89 \\
\%\end{array}$ & $\begin{array}{r}' 94 \\
\%\end{array}$ \\
\hline $\begin{array}{l}\text { Vakkennis } \\
\text { Vakspecifieke } \\
\text { methoden en }\end{array}$ & - & 4 & 7 & 6 & 14 & 7 & - & 8 & 11 & 7 \\
\hline technieken & - & 11 & 2 & 6 & 9 & 9 & - & 16 & 9 & 10 \\
\hline $\begin{array}{l}\text { Computergebruik } \\
\text { Met cijfers om }\end{array}$ & - & 31 & 71 & 61 & 39 & 29 & - & 39 & 52 & 35 \\
\hline $\begin{array}{l}\text { kunnen gaan } \\
\text { Communicatieve }\end{array}$ & - & 7 & 11 & 6 & 9 & 15 & - & 33 & 13 & 15 \\
\hline $\begin{array}{l}\text { vaardigheden } \\
\text { Werken in }\end{array}$ & - & 23 & 4 & 0 & 20 & 19 & - & 35 & 14 & 21 \\
\hline $\begin{array}{l}\text { teamverband } \\
\text { Plannen en }\end{array}$ & - & 6 & 16 & 3 & 18 & 4 & - & 2 & 13 & 4 \\
\hline organiseren & - & 34 & 40 & 46 & 25 & 30 & - & 29 & 31 & 33 \\
\hline Leidinggeven & - & 49 & 51 & 39 & 29 & 42 & - & 37 & 33 & 43 \\
\hline Zelfstandigheid & - & 0 & 11 & 3 & 0 & 2 & - & 2 & 4 & 2 \\
\hline Creativiteit & - & 23 & 11 & 3 & 18 & 24 & - & 20 & 17 & 20 \\
\hline $\begin{array}{l}\text { Initiatief } \\
\text { Omgaan met en } \\
\text { inspelen op }\end{array}$ & - & 16 & 7 & 3 & 4 & 5 & - & 6 & 4 & 8 \\
\hline veranderingen & - & 44 & 13 & 12 & 27 & 35 & - & 14 & 21 & 31 \\
\hline $\begin{array}{l}\text { Nauwkeurigheid } \\
\text { Internationale }\end{array}$ & - & 6 & 2 & 6 & 5 & 5 & - & 2 & 5 & 5 \\
\hline oriëntatie & & 4 & 9 & 15 & 29 & 21 & - & 18 & 16 & 16 \\
\hline $\begin{array}{l}\text { Aantal } \\
\text { respondenten }\end{array}$ & 4 & 71 & 45 & 33 & 56 & 136 & 23 & 51 & 128 & 291 \\
\hline
\end{tabular}

* Deel dat aangeeft dat betreffende competentie te weinig aan bod is gekomen. Percenteerbasis is de groep die aangegeven heeft dat minimaal één competentie te weinig aan bod is gekomen.

'-' de groep is te klein om over te rapporteren

Verschil met tekorten in de opleiding aan het begin van de loopbaan

Om erachter te komen of men aan het begin van de loopbaan andere tekorten ervaart dan verderop in de loopbaan, wordt in tabel 5.3 voor cohort '94 een vergelijking gemaakt tussen de tekorten die men een jaar na afstuderen noemt en de 
tekorten die men vijf jaar na afstuderen noemt. Van cohort '94 hebben 181 personen de vraag over de tekorten in beide jaren ingevuld. De vraagstelling was in beide jaren echter niet gelijk. Een jaar na afstuderen is gevraagd of aan een competentie minder, evenveel of meer aandacht besteed zou moeten worden dan tijdens de opleiding het geval was. Vijf jaar na afstuderen is gevraagd naar die competenties (maximaal drie) waarvan men vindt dat deze in de opleiding te weinig aan bod zijn gekomen. Vanwege deze verschillen in vraagstelling zullen er - net als in tabel 3.3 - geen percentages maar rangordenummers gepresenteerd worden. Over de verschillen tussen de studierichtingen zijn moeilijk betrouwbare uitspraken te doen aangezien het aantal medici en juristen erg klein is.

Zowel aan het begin als verderop in de loopbaan blijken computergebruik, leidinggeven en plannen en organiseren de belangrijkste tekorten te zijn in de opleiding. Wel zien we dat gezondheidswetenschappers gaandeweg de loopbaan liever meer aandacht in de opleiding zouden willen voor communicatieve vaardigheden dan een jaar na afstuderen. Wellicht is het belang van goede communicatieve vaardigheden voor gezondheidswetenschappers tijdens de loopbaan toegenomen. Vijf jaar na afstuderen blijken communicatieve vaardigheden namelijk vaak op zeer hoog niveau vereist te zijn (zie tabel 3.2). Verder is te zien dat men vijf jaar na afstuderen minder vaak een tekort aan vakspecifieke methoden en technieken ervaart dan een jaar na afstuderen. Hierbij kan een rol spelen dat vakspecifieke methoden en technieken gaandeweg de loopbaan iets minder belangrijk worden (zie tabel 3.3). Ook zou het kunnen zijn dat men deze methoden en technieken in de vijf jaar na afstuderen tijdens het werk goed eigen heeft kunnen maken.

Tabel 5.3

Tekorten in de opleiding tijdens de loopbaan (één en vijf jaar na afstuderen) a.h.v. rangordenummers, cohort ' 94 *

\begin{tabular}{|c|c|c|c|c|c|c|c|c|c|c|}
\hline \multirow[b]{2}{*}{ Jaar na afstuderen: } & \multicolumn{2}{|c|}{ FdEWB } & \multicolumn{2}{|c|}{$\mathrm{FdG}^{* *}$} & \multicolumn{2}{|c|}{ FdGW } & \multicolumn{2}{|c|}{$\mathrm{FdR}^{\star *}$} & \multicolumn{2}{|c|}{ UM Totaal } \\
\hline & $1 \mathrm{jr}$. & $5 \mathrm{jr}$. & $1 \mathrm{jr}$. & $5 \mathrm{jr}$. & $1 \mathrm{jr}$. & $5 \mathrm{jr}$. & $1 \mathrm{jr}$. & $5 \mathrm{jr}$. & $1 \mathrm{jr}$. & $5 \mathrm{jr}$. \\
\hline Vakkennis & 8 & 7 & 3 & 6 & 6 & 7 & 3 & 7 & 6 & 7 \\
\hline $\begin{array}{l}\text { Vakspecifieke methoden en } \\
\text { technieken }\end{array}$ & 4 & 5 & 5 & 7 & 4 & 6 & 6 & 6 & 4 & 6 \\
\hline Computergebruik & 2 & 3 & 1 & 1 & 1 & 3 & 2 & 2 & 1 & 2 \\
\hline $\begin{array}{l}\text { Met cijfers om kunnen gaan } \\
\text { Communicatieve }\end{array}$ & 6 & 6 & 4 & 4 & 5 & 5 & 7 & 3 & 5 & 5 \\
\hline vaardigheden & 5 & 4 & 6 & 8 & 8 & 4 & 5 & 5 & 7 & 4 \\
\hline Plannen en organiseren & 3 & 2 & 7 & 2 & 3 & 2 & 1 & 4 & 3 & 3 \\
\hline Leidinggeven & 1 & 1 & 2 & 3 & 2 & 1 & 4 & 1 & 2 & 1 \\
\hline Nauwkeurigheid & 7 & 8 & 8 & 5 & 7 & 8 & 8 & 8 & 8 & 8 \\
\hline
\end{tabular}

* Een jaar na afstuderen betreft het deel dat aangegeven heeft meer aandacht te willen voor een bepaalde competentie en is de percenteerbasis de groep die de vraag heeft ingevuld. Vijf jaar na afstuderen betreft het deel dat aangeeft dat een bepaalde competentie te weinig aan bod is gekomen en is de percenteerbasis de groep die aangeeft dat minimaal één competentie te weinig aan bod is gekomen. Zie bijlage voor precieze percentages.

** De groep is te klein om betrouwbare conclusies te kunnen trekken. 


\subsection{Voorbereiding van de opleiding op het werk}

In deze paragraaf zullen we bekijken hoe de opleiding studenten heeft voorbereid op hun werk. Hebben UM-afgestudeerden tijdens hun opleiding voldoende kennis en vaardigheden opgedaan voor hun werk?

In figuur 5.1 is te zien dat de meerderheid van de UM-afgestudeerden vindt dat zij tijdens de opleiding voldoende hebben geleerd om te kunnen beginnen met werken. Meer dan de helft vindt echter dat zij nog niet voldoende kennis en vaardigheden heeft om de huidige functie adequaat te vervullen. Ongeveer de helft van de UMafgestudeerden geeft ook aan dat zij met additionele kennis en vaardigheden het werk beter zouden kunnen vervullen. In de banen van UM-afgestudeerden is dus nog volop ontwikkeling mogelijk (zie ook figuur 3.1 en figuur 4.2) en kan men nog veel bijleren. Voor de verdere ontwikkeling van kennis en vaardigheden is volgens het merendeel van de UM-afgestudeerden een goede basis gelegd tijdens de opleiding. Wanneer we kijken naar de verschillen tussen de studierichtingen, dan zien we dat het werk van medici het meest aansluit op de kennis en vaardigheden die zij in de opleiding hebben opgedaan. Dit is niet zo verwonderlijk aangezien de aansluiting tussen de opleiding en het werk qua niveau en richting bij geneeskunde beter is dan bij de andere studierichtingen (zie paragraaf 2.2.1). Dit komt doordat de opleiding geneeskunde specifiek gericht is op het beroep van arts, terwijl de andere studierichtingen gericht zijn op een breder beroepenveld. Juristen geven het minst vaak aan voldoende kennis en vaardigheden in de opleiding opgedaan te hebben voor het werk. Specifieke beroepskennis en -vaardigheden zullen zij vaak nog tijdens het werk moeten leren. Dit zal niet veel problemen geven aangezien de meerderheid van de juristen wel vindt dat de opleiding hen voldoende kennis en vaardigheden heeft bijgebracht om zich verder te kunnen ontwikkelen.

De meerderheid van de UM-afgestudeerden zou dezelfde opleiding achteraf bezien opnieuw kiezen en heeft dus geen spijt van de gekozen opleiding (zie figuur 5.2). Gezondheidswetenschappers zijn in vergelijking tot andere UM-afgestudeerden het minst tevreden met hun opleidingskeuze en medici het meest.

\subsection{Conclusie}

Voor de meeste competenties is het werk een belangrijkere leerbron dan de opleiding. Computergebruik, plannen en organiseren, leidinggeven, omgaan met- en inspelen op veranderingen blijkt men voornamelijk op het werk te leren. Voor vakspecifieke competenties en werken in teamverband blijkt naast het werk ook de opleiding een belangrijke leerbron te zijn. Andere competenties, zoals communicatieve vaardigheden, zelfstandigheid, nauwkeurigheid, creativiteit worden ook vaak elders geleerd.

In de opleiding worden vooral tekorten ervaren met betrekking tot computergebruik, plannen en organiseren, leidinggeven en omgaan met en inspelen op veranderingen. De in de opleiding opgedane kennis en vaardigheden zijn vaak onvoldoende om het 
huidige werk adequaat te kunnen vervullen, maar geven wel een goede basis voor de verdere ontwikkeling van kennis en vaardigheden. De meerderheid van de UMafgestudeerden heeft achteraf bezien geen spijt van de gemaakte opleidingskeuze.

\section{Figuur 5.1}

Voorbereiding van de opleiding op het werk vijf en tien jaar na afstuderen, resp. cohort '94 en cohort ' 89

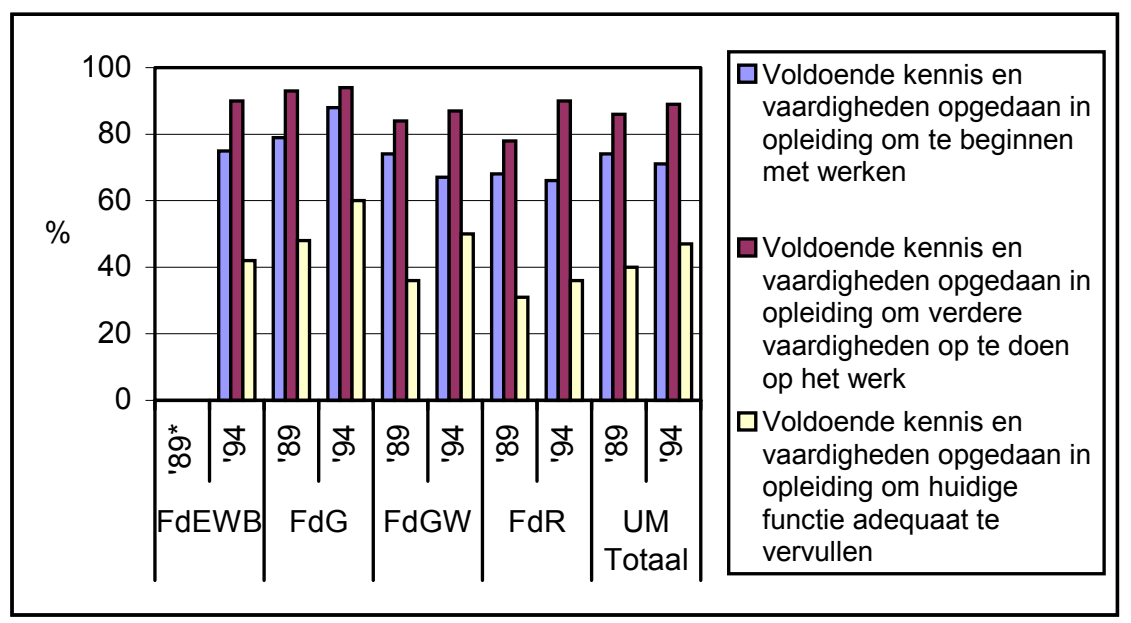

* de groep is te klein om over te rapporteren

Figuur 5.2

Tevredenheid met opleidingskeuze vijf en tien jaar na afstuderen, resp. cohort '94 en cohort '89

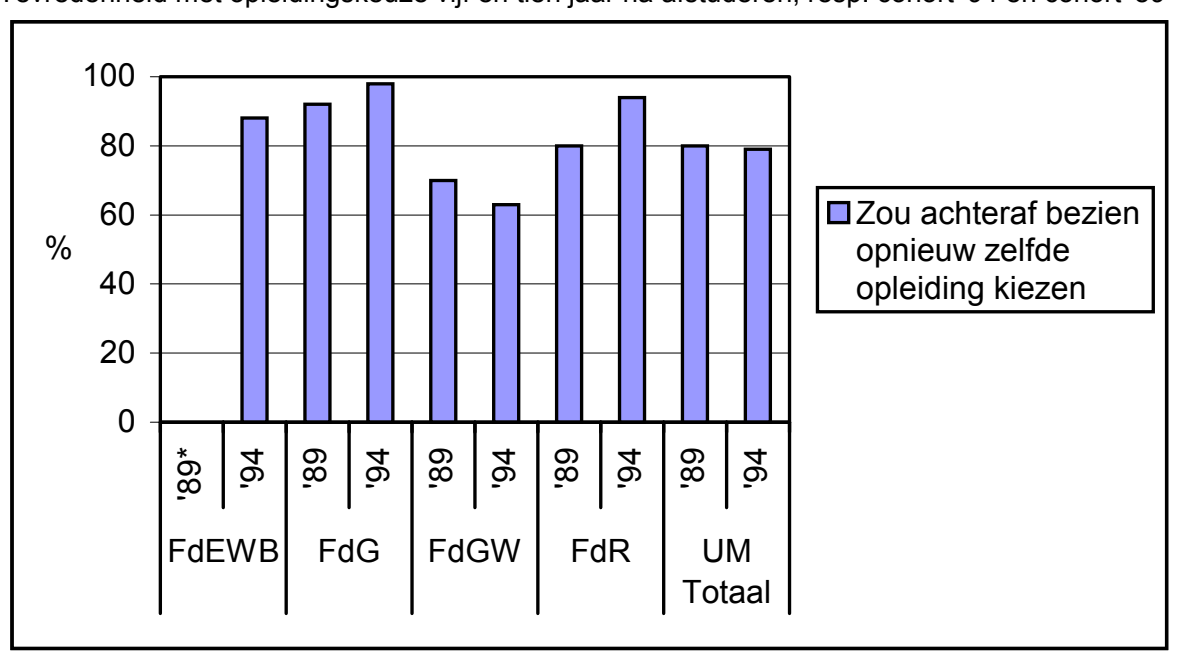

* de groep is te klein om over te rapporteren 


\section{Bijlage}

Tabel bij Figuur 2.1

Maatschappelijke positie vijf en tien jaar na afstuderen, resp. cohort '94 en cohort ' 89

\begin{tabular}{|c|c|c|c|c|c|c|c|c|c|c|}
\hline \multirow[b]{2}{*}{ Cohort: } & \multicolumn{2}{|c|}{ FdEWB } & \multicolumn{2}{|c|}{ FdG } & \multicolumn{2}{|c|}{ FdGW } & \multicolumn{2}{|c|}{ FdR } & \multicolumn{2}{|c|}{ UM Totaal } \\
\hline & $\begin{array}{r}\text { '89 } \\
\%\end{array}$ & $\begin{array}{r}' 94 \\
\%\end{array}$ & $\begin{array}{r}' 89 \\
\%\end{array}$ & $\begin{array}{r}' 94 \\
\%\end{array}$ & $\begin{array}{r}\text { '89 } \\
\%\end{array}$ & $\begin{array}{r}' 94 \\
\%\end{array}$ & $\begin{array}{r}\text { '89 } \\
\%\end{array}$ & $\begin{array}{r}' 94 \\
\%\end{array}$ & $\begin{array}{r}' 89 \\
\%\end{array}$ & $\begin{array}{r}' 94 \\
\%\end{array}$ \\
\hline $\begin{array}{l}\text { Betaald } \\
\text { werk }\end{array}$ & - & 99 & 85 & 86 & 87 & 92 & 88 & 98 & 87 & 94 \\
\hline Studie & - & & & 4 & 1 & 2 & & & 1 & 2 \\
\hline Werkloos & - & & & 2 & 1 & 1 & & & 1 & 1 \\
\hline Zorg & - & & 3 & & 1 & 2 & 6 & & 3 & 1 \\
\hline Anders & - & 1 & 12 & 9 & 9 & 3 & 6 & 2 & 9 & 3 \\
\hline
\end{tabular}

Tabel bij Figuur 2.2

Maatschappelijke positie een jaar (meetjaar 1995) en vijf jaar (meetjaar 2000) na afstuderen, cohort '94

\begin{tabular}{|c|c|c|c|c|c|c|c|c|c|c|}
\hline \multirow[b]{2}{*}{$\begin{array}{l}\text { Jaar na } \\
\text { afstuderen: }\end{array}$} & \multicolumn{2}{|c|}{$\begin{array}{c}\text { FdEWB } \\
(n=75)\end{array}$} & \multicolumn{2}{|c|}{$\begin{array}{l}F_{d G}^{*} \\
(n=38)\end{array}$} & \multicolumn{2}{|c|}{$\begin{array}{c}\text { FdGW } \\
(n=155)\end{array}$} & \multicolumn{2}{|c|}{$\begin{array}{l}\mathrm{FdR}^{*} \\
(\mathrm{n}=40)\end{array}$} & \multicolumn{2}{|c|}{$\begin{array}{l}\text { UM Totaal } \\
(n=308)\end{array}$} \\
\hline & $1 \mathrm{jr}$. & $\begin{array}{r}5 \mathrm{jr} . \\
\%\end{array}$ & $\begin{array}{r}1 \mathrm{jr} . \\
\%\end{array}$ & 5 jr. & $1 \mathrm{jr}$. & $\begin{array}{r}5 \mathrm{jr} . \\
\%\end{array}$ & $\begin{array}{l}1 \mathrm{jr} . \\
\%\end{array}$ & 5 jr. & 1 jr. & $\begin{array}{r}5 \mathrm{jr} . \\
\%\end{array}$ \\
\hline Betaald werk & 86 & 99 & 97 & 87 & 80 & 93 & 93 & 100 & 86 & 94 \\
\hline Studie & 3 & 0 & 3 & 3 & 6 & 2 & 5 & & 4 & 1 \\
\hline Werkloos & 7 & 0 & 0 & 3 & 7 & 1 & 3 & & 6 & 1 \\
\hline Anders & 4 & 1 & 0 & 8 & 7 & 4 & 0 & & 4 & 4 \\
\hline
\end{tabular}

* de groep is te klein om op basis van de gepresenteerde percentages betrouwbare conclusies te kunnen trekken 


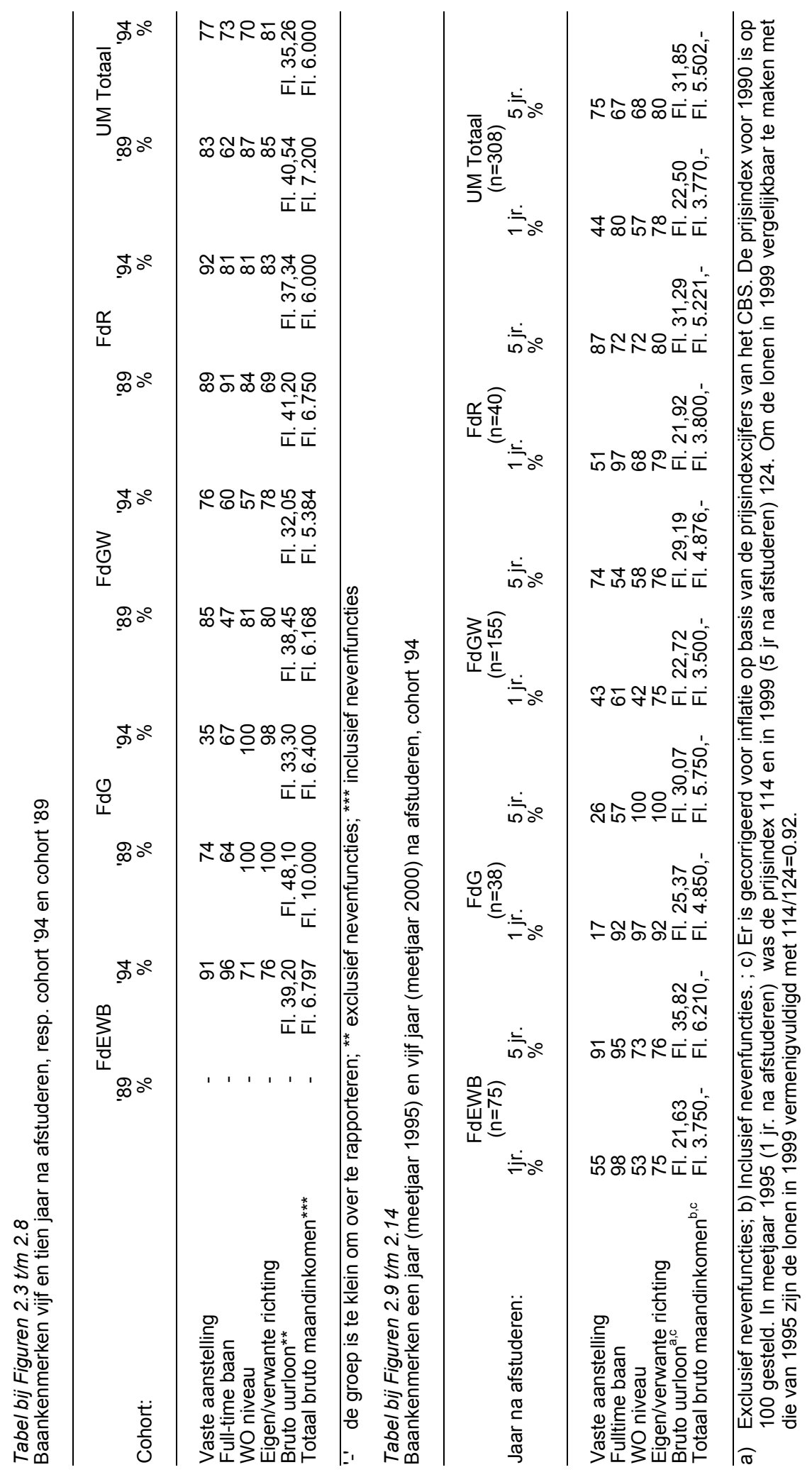




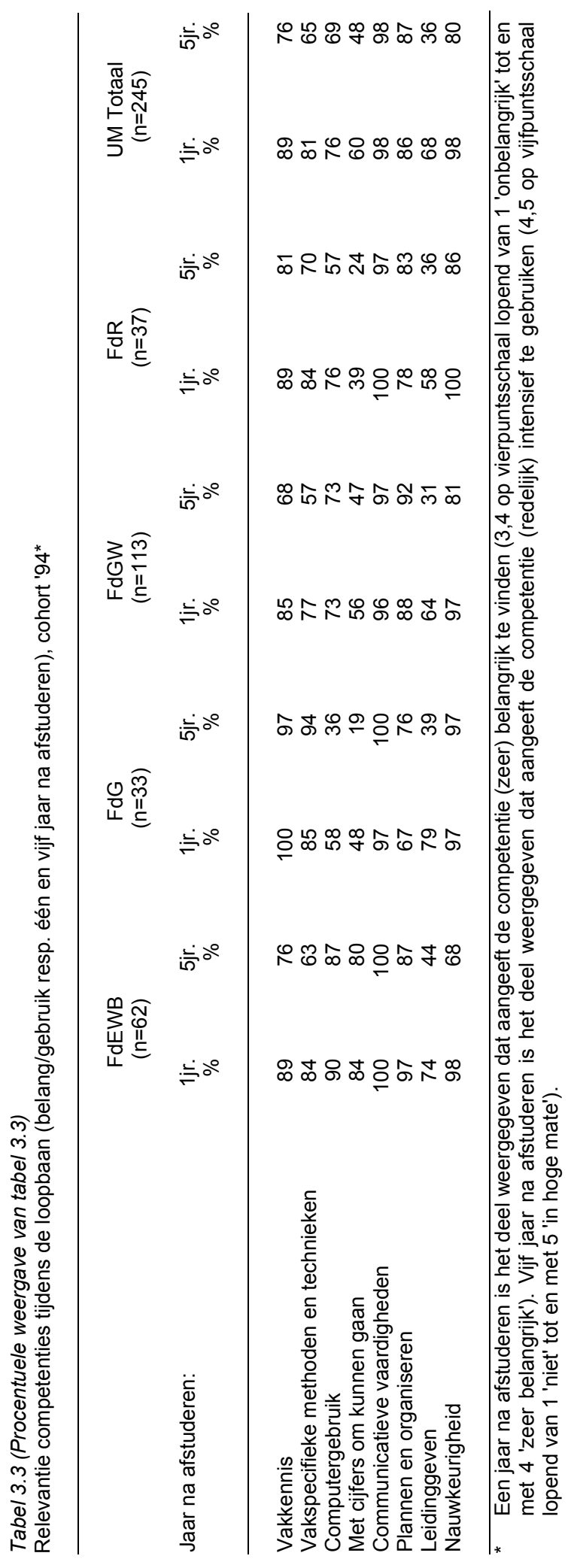




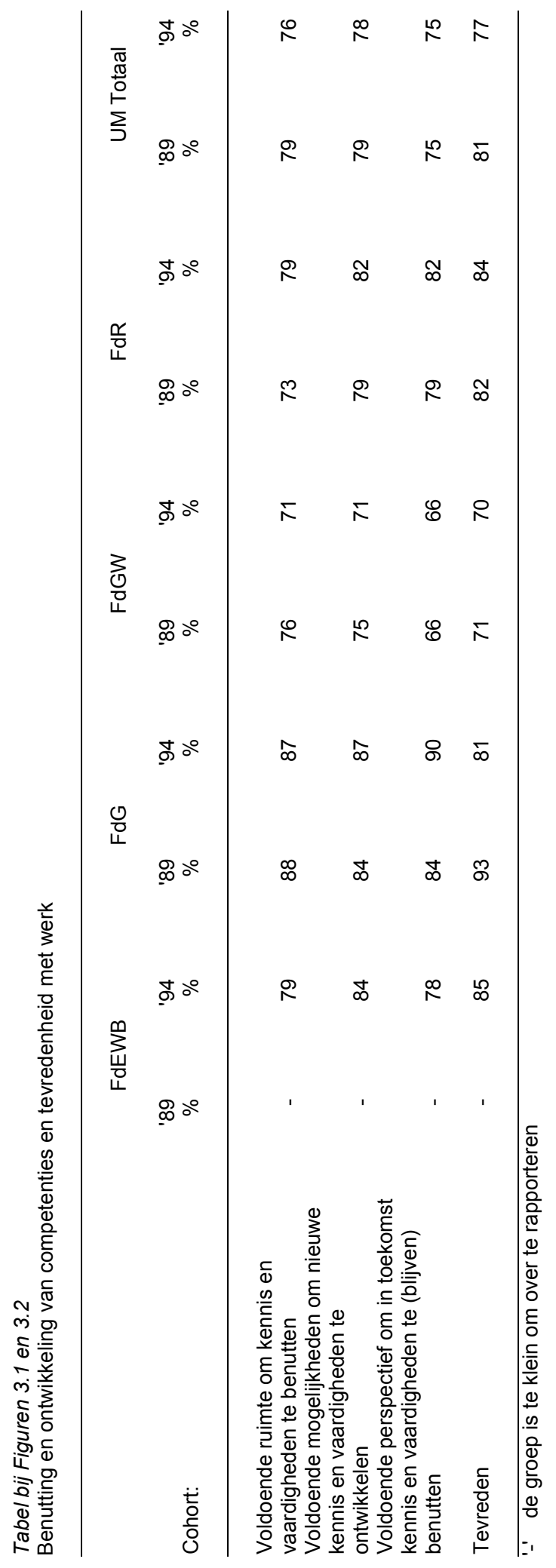




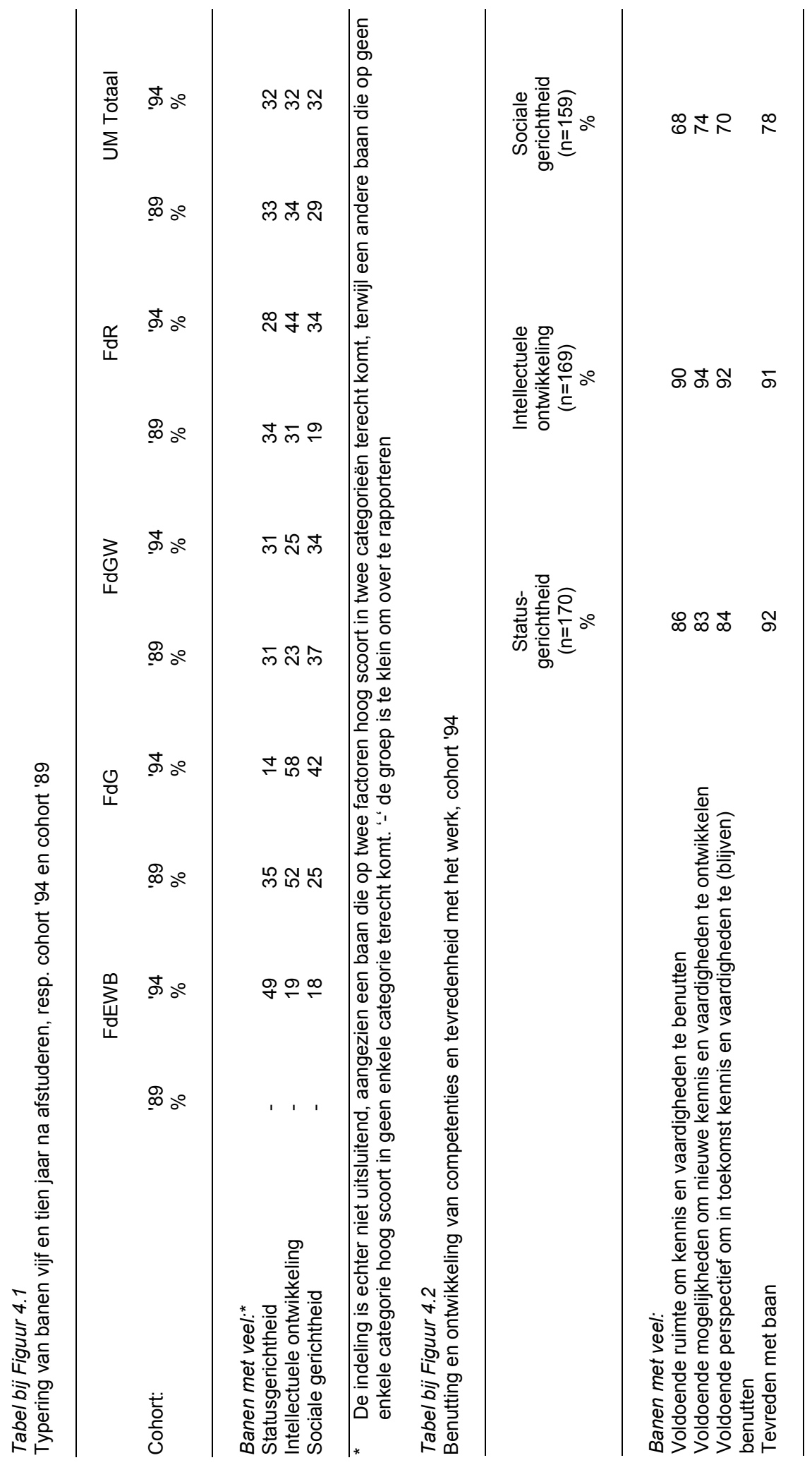




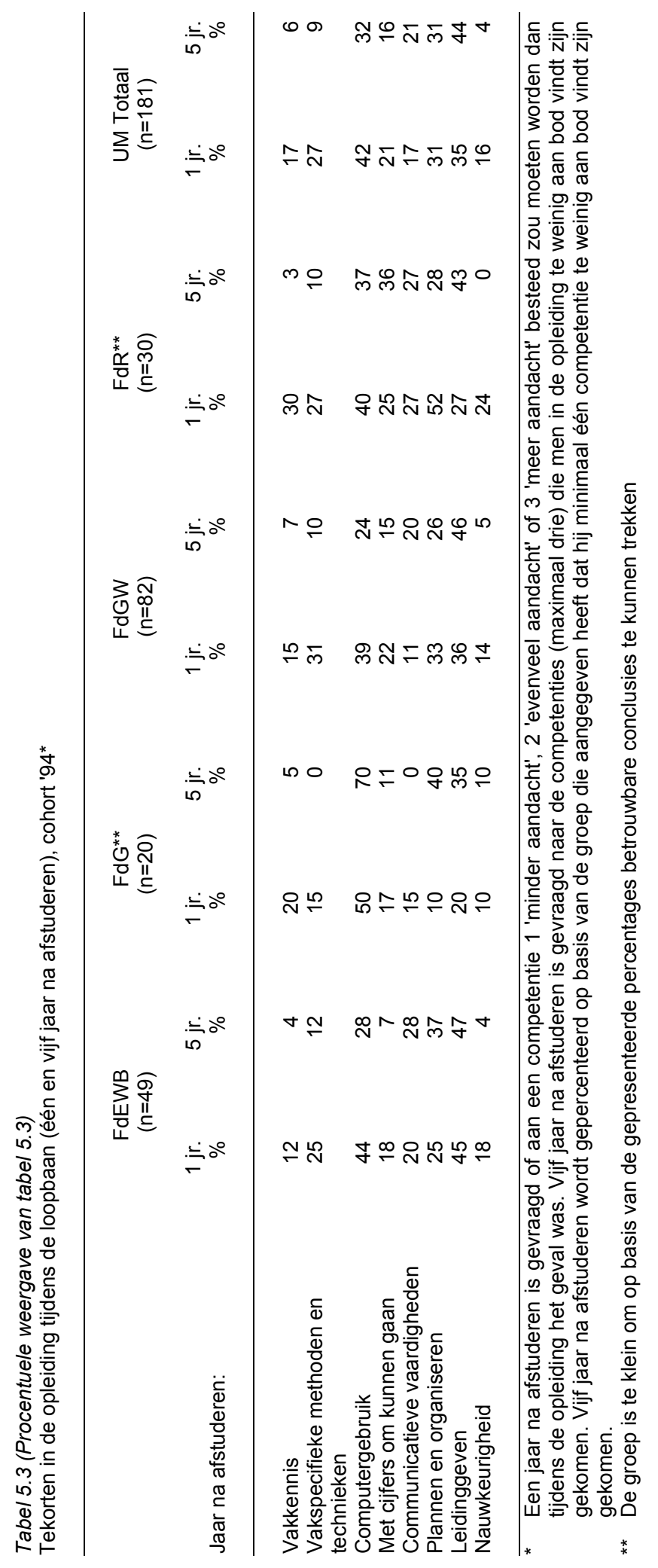




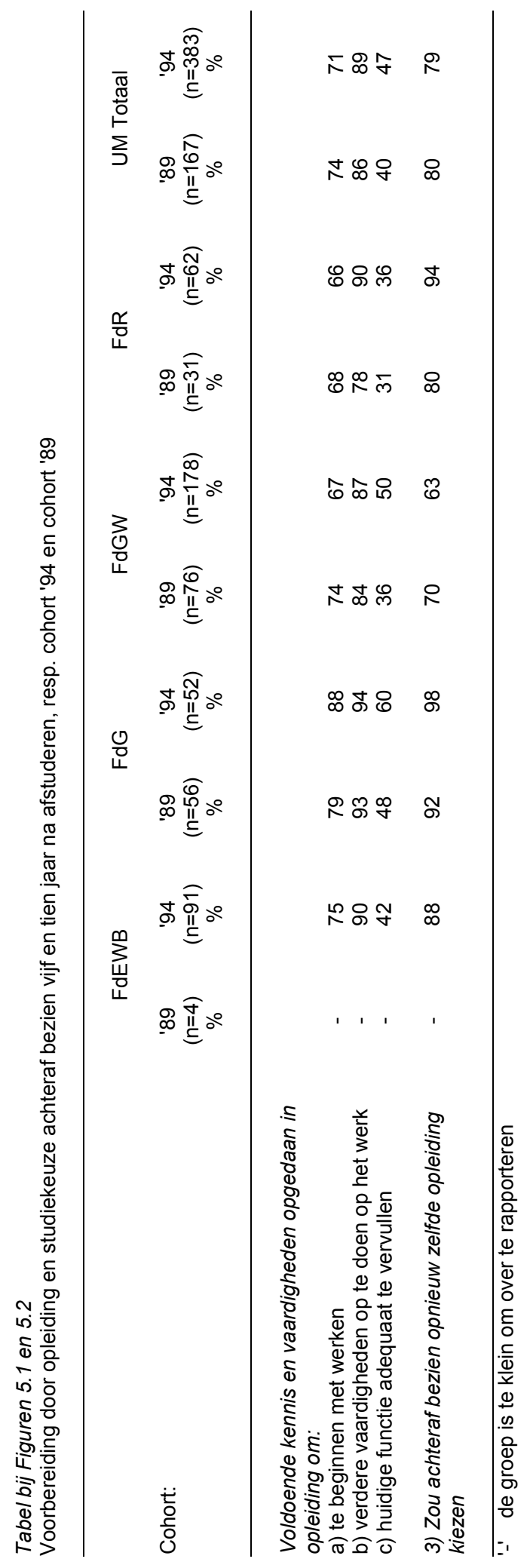

